\title{
Coexpression of mRNAs for NGF, BDNF, and NT-3 in the Cardiovascular System of the Pre- and Postnatal Rat
}

\author{
I. A. Scarisbrick, ${ }^{1}$ E. G. Jones, ${ }^{1}$ and P. J. Isackson ${ }^{1,2, a}$ \\ Departments of 'Anatomy and Neurobiology and ${ }^{2}$ Biological Chemistry, University of California, Irvine, California 92717
}

The expression of NGF, brain-derived neurotrophic factor (BDNF) and neurotrophin-3 (NT-3) mRNAs was examined in whole rat embryos and in the heart and great vessels of postnatal and adult rats, using in situ hybridization of CRNA probes. The patterns of expression were correlated with innervation patterns as revealed by immunostaining for neural cell adhesion molecule (NCAM) and with the HNK-1 antibody, which demonstrates derivatives of the neural crest. The patterns of neurotrophin mRNA localization were different from those of mRNAs for the low-molecular-weight NGF receptor. Hybridization indicating the presence of mRNAs for all three neurotrophins is particularly prominent within the tunica media of the aorta, pulmonary, and other major elastic arteries of the thorax and abdomen and is first observed on embryonic day 13 (E13) when innervation is being established and rises to maximum by E15. In the fetus, there is little or no detectable expression in the CNS or PNS. NT-3 expression in the vessels is relatively constant and high from embryonic to adult stages, while levels of BDNF increase and those of NGF decrease over the same time course. During the fetal period, hybridization in the heart is absent. In the postnatal period, additional label becomes detectable in the coronary arteries but not in the walls of the atria or ventricles, other than at the base of the aorta and pulmonary trunk. The pattern of expression of the three neurotrophins suggests that all three may be expressed by the same muscle cells of the elastic arteries and therefore may act on the same postganglionic or sensory neurons innervating the great vessels and coronary arteries. Neurotrophin mRNA expression by muscle cells in the major elastic arteries occurs only after nerve fibers have arrived at the vessels and correlates with the derivation of these distributing arteries from cardiac neural crest cells. Changes in expression of neurotrophin mRNAs over the course of development, and their continued expression in the adult, suggest that members of the NGF neurotrophin family are likely to play different roles at different stages of development.

[Key words: nerve growth factor, brain derived neurotrophic factor, neurotrophin-3, development, in situ hybridization, heart, blood vessels, coronary arteries, peripheral nervous system]

Received Feb. 14, 1992; revised July 15, 1992; accepted July 29, 1992.

This work was supported hy Grants NS21377, MH44188, and NS24747 from the National Institutes of Health, United States Public Health Service; by a predoctoral training grant from the Easter Seal Research Institute of Ontario; and by the Irvine Research Unit in Molecular Neurobiology. We thank Dr. G. M. Edelman for providing the antiserum to NCAM.

Correspondence should be addressed to Dr. E. G. Jones at the above address.

apresent address: Department of Biochemistry and Molecular Biology, Mayo Clinic, Jacksonville, FL 32224.

Copyright (C) 1993 Society for Neuroscience $0270-6474 / 93 / 130875-19 \$ 05.00 / 0$
During embryonic development, neuronal populations are initially produced in excess and undergo a phase of naturally occurring cell death that is regulated by competition for targetderived neurotrophic factors (Hamburger and Levi-Montalcini, 1949; Oppenheim et al., 1982). NGF, the most extensively studied example of a target-derived neurotrophic factor (LeviMontalcini and Angeletti, 1968), is produced in neuronal and non-neuronal target tissues and provides trophic support for sympathetic neurons and neural crest-derived sensory neurons in the PNS and for certain cholinergic neurons in the CNS (Alderson et al., 1990; Hefti, 1986). The dependence of sympathetic and sensory neurons on NGF varies over time: sympathetic neurons remain dependent upon NGF for survival throughout life, whereas neural crest-derived, sensory neurons are dependent on NGF only during a restricted period of embryonic development (Cohen, 1960; Levi-Montalcini and Booker, 1960a,b; Levi-Montalcini and Angeletti, 1968; Aguayo et al., 1976; Hendry and Campbell, 1976; Nja and Purves, 1978; Hamburger et al., 1981; Oppenheim, 1981). In adults, levels of NGF mRNA in target tissues of the sympathetic nervous system are proportional to the extent of innervation by sympathetic fibers (Korsching and Thoenen, 1983; Shelton and Reichardt, 1984), but in the case of sensory innervation, levels of NGF mRNA are not correlated with target field innervation (Shelton and Reichardt, 1984).

Two other neurotrophic factors, brain-derived neurotrophic factor (BDNF) and neurotrophin-3 (NT-3), have recently been characterized and found to be very similar in structure to NGF (Barde et al., 1982; Leibrock et al., 1989; Hohn et al., 1990; Maisonpierre et al., 1990a). Each of the neurotrophins is produced as a 240-260 amino acid precursor that is processed to produce a 118-120 amino acid mature factor from the C-terminus that is $50-60 \%$ identical in amino acid sequence. The biologically active form of NGF is known to be a tightly associated dimer (McDonald et al., 1991) that acts on multiple receptors including a high-affinity receptor associated with a tyrosine protein kinase coded for by the proto-oncogene trkA (Hempstead et al., 1991). BDNF and NT-3 presumably also exist as dimers and bind to receptors associated with other tyrosine protein kinases coded by other members of the trk gene family, and may form complexes with the low-molecular-weight NGF receptor (NGF-R; Lamballe et al., 1991; Soppet et al., 1991; Squinto et al., 1991).

BDNF and NT-3 have been found to influence neuronal populations that only partially overlap with those supported by NGF. All three factors support the survival of dissociated sensory cells of chick dorsal root ganglia (Lindsay et al., 1985; Davies et al., 1986; Kalcheim et al., 1987; Maisonpierre et al., 1990 a), but they differ in their effects on sympathetic neurons. 
NGF and NT-3 increase the survival of chick embryonic sympathetic neurons in culture, whereas BDNF has no effect (Lindsay et al., 1985; Rosenthal et al., 1990). NT-3, like NGF, induces neurite extension of neurons in sympathetic ganglion explants (Maisonpierre et al., 1990a), but only at concentrations 10-20fold higher than necessary with NGF; BDNF has no effect. Heart explants support neurite extension from sensory neurons in vitro (Ebendal, 1979), and BDNF and NT-3 induce neurite extension and increase the survival of placode-derived sensory neurons of the nodose ganglion that innervates visceral structures including the heart and great vessels; NGF has no effect (Hohn et al., 1990; Maisonpierre et al., 1990a; Rosenthal et al., 1990). No effects of NGF, BDNF, or NT-3 have been observed on parasympathetic neurons cultured from ciliary ganglia (Maisonpierre et al., 1990a); however, heart explants promote neurite outgrowth from this neuronal population (Ebendal, 1979). The heart and great vessels of the thorax provide an opportunity to examine the potential differential effects of the three neurotrophins on three neuronal populations during development since they are innervated by sympathetic, parasympathetic, and sensory neurons. These three neuronal populations have different embryonic origins, namely, the neural tube, neural crest, and certain neurogenic placodes (Narayanan and Narayanan, 1980; Le Douarin, 1982), whilc the smooth muscle cells of the major elastic arteries arise from the cranial neural crest (Le Lievre and Le Douarin, 1975).

Virtually all previous studies of localization of mRNAs for the three neurotrophins in the PNS of adult and developing animals have been based upon Northern blot analysis and have been done on a regional or organ basis, extracting mRNA from, for example, the iris, the heart, or the maxillary process, which are known targets of neural crest-derived sympathetic and/or sensory neurons (Korsching and Thoenen, 1983; Rohrer et al., 1988; Clegg et al., 1989; Maisonpierre et al., 1990b). Exact histological localization of mRNAs based upon in situ hybridization histochemistry has been applied in relatively few studies (Bandtlow et al., 1987; Davies et al., 1987), and some target organs, notably the blood vessels and gut and other targets of visceral afferents, have received little attention. Northern blot analysis of tissues in the developing rat has shown that expression of mRNAs for all three factors is first detectable at embryonic day 12 (E12) (Maisonpierre et al., 1990b). NT-3 mRNA is reported to be expressed at higher levels than NGF mRNA in the embryonic heart, while BDNF mRNA is not expressed at detectable levels there. NGF mRNA levels in the fetal and neonatal rat heart are reported to be highest in the ventricles and are not affected by sympathectomy (Clegg et al., 1989). As a further step toward developing an understanding of the respective roles of NGF, BDNF, and NT-3 in the developing PNS, we have used in situ hybridization to localize cells producing mRNAs for each of these factors in rat heart and great vessels during middle and late phases of fetal development, in early postnatal life, and in the adult.

\section{Materials and Methods}

Subjects and histology. Rat fetuses of known gestational ages were obtained by placing an adult Wistar male with a single Wistar female from 5:00 P.M. to 9:00 A.M. When a vaginal plug was identified, this was considered to be embryonic day zero (E0). Fetuses, ranging in age from E12 to E18, were retrieved from the deeply anesthetized female and fixed by immersion in a solution of $5 \%$ acetic acid and $5 \%$ formalin in $80 \%$ alcohol for $24 \mathrm{hr}$ at $4^{\circ} \mathrm{C}$. They were then washed overnight in running tap water, dehydrated in alcohols, cleared in butanol, and embedded in Paraplast. The heart and associated blood vessels were retrieved from anesthetized postnatal day zero $(\mathrm{P} 0)$ and adult animals. Tissue was rinsed in saline, and then immersed in the same fixative and embedded as above. A further series of animals at ages P0, P7, and adult were perfused with $4 \%$ paraformaldehyde. The brains were removed and also embedded in Paraplast as above.

Preparation of probes. Rat NGF cRNA probes were prepared from pBSrNGF, a rat genomic clone of NGF, provided by Dr. Scott Whittemore (Whittemore et al., 1988). Transcription of EcoRI-linearized pBSrNGF with T7 RNA polymerase produces an 800 base probe complementary to NGF mRNA. Sense-strand control probes were prepared from PvuII-linearized pBSrNGF with T3 RNA polymerase.

Antisense- and sense-strand rat BDNF RNA probes were prepared from PvuII-linearized pR1112-8 (Isackson et al., 1991) with T3 RNA polymerase and T7 RNA polymerase, respectively. The cRNA probe generated in this manner contains 384 bases complementary to the BDNF mRNA region coding for mature BDNF.

A 392 base pair region of rat genomic DNA corresponding to bases 481-873 of the published rat NT-3 cDNA sequence (Maisonpierre et al., 1990a) was obtained by polymerase chain reaction amplification and inserted into the HincII site of pBS (Stratagene) to produce pRNT31. Antisense- and sense-strand RNA probes were transcribed from PvuIIlinearized pRNT3-1 with T3 and T7 RNA polymerase, respectively.

A cDNA clone to rat NGF receptor (NGF-R; p5a) was provided by M. V. Chao. After linearization with HaeII, the NGF-R cDNA, 2300 bases in length, was transcribed with T3 RNA polymerase and labeled with $\alpha-{ }^{35}$ S-UTP.

A cDNA clone to rat cyclophilin (pl B1 5, Danielson et al., 1988) was transcribed with T7 RNA polymerase to produce a 680 base antisense cRNA probe.

In situ hybridization. Paraplast-embedded tissue was sectioned in the parasagittal plane at a thickness of $20 \mu \mathrm{m}$. Serial sections were mounted on acid-washed, poly-L-lysine (Sigma)-coated slides. Slide-mounted sections were then dehydrated in an ascending series of alcohols, dewaxed in xylene overnight, cleared in butanol, and rehydrated in preparation for in situ hybridization.

Series of alternating sections were processed to identify cells expressing the mRNAs that encode NGF, BDNF, NT-3, cyclophilin, or NGF receptor using $\alpha-{ }^{35} \mathrm{~S}-\mathrm{UTP}$-labeled cRNA probes as described above. Hybridization was performed following the method of Gall and Isackson (1989). The slide-mounted sections were washed in $0.1 \mathrm{M}$ glycine in 0.1 $M$ phosphate buffer ( $\mathrm{pH} \mathrm{7.2)}$, and then incubated in $1 \mu \mathrm{g} / \mathrm{ml}$ proteinase $\mathrm{K}, 50 \mathrm{~mm}$ EDTA, $0.1 \mathrm{~m}$ Tris- $\mathrm{Cl}(\mathrm{pH} 8)$ for $30 \mathrm{~min}$ at $30^{\circ} \mathrm{C}$. They were then treated with $0.25 \%$ acetic anhydride in $0.1 \mathrm{M}$ triethanolamine $(\mathrm{pH}$ $8.0)$ for $10 \mathrm{~min}$ at room temperature and washed in $2 \times \operatorname{SSC}(0.3 \mathrm{M}$ $\mathrm{NaCl}, 0.3 \mathrm{M}$ sodium citrate). Hybridization buffer containing $50 \%$ deionized formamide, $10 \%$ dextran sulfate, $0.7 \%$ Ficoll, $0.7 \%$ polyvinyl pyrolidone, $0.7 \%$ bovine serum albumin, $0.15 \mathrm{mg} / \mathrm{ml}$ yeast tRNA, 0.33 $\mathrm{mg} / \mathrm{ml}$ denatured herring sperm DNA, $40 \mu \mathrm{M}$ dithiothreitol, and $1 \times$ $10^{4} \mathrm{cpm} / \mu \mathrm{l}$ of the ${ }^{35} \mathrm{~S}-\mathrm{UTP}$-labeled antisense riboprobe was applied to the slide-mounted sections, which were then covered with a coverslip and incubated for $48 \mathrm{hr}$ at $60^{\circ} \mathrm{C}$. The hybridized sections were then washed in $4 \times$ SSC and treated with $20 \mu \mathrm{g} / \mathrm{ml}$ ribonuclease $\mathrm{A} .10 \mathrm{~mm}$ Tris- $\mathrm{HCl}, 1 \mathrm{~mm}$ EDTA ( $\mathrm{pH}$ ) for $30 \mathrm{~min}$ at $45^{\circ} \mathrm{C}$, followed by washing in SSC solutions of decreasing concentration, containing $6.4 \mathrm{~mm}$ sodium thiosulfate, at room temperature. Finally, the sections were washed in $0.1 \times \mathrm{SSC}$, with sodium thiosulfate, at $60^{\circ} \mathrm{C}$ for $1 \mathrm{hr}$, dried, applied to Amersham Beta Max x-ray film, and exposed for $4-7 \mathrm{~d}$ at $4^{\circ} \mathrm{C}$. After development of the film, they were coated with Kodak NTB2 emulsion, exposed for $21-30 \mathrm{~d}$ at $4^{\circ} \mathrm{C}$, developed in Kodak D19, fixed, and stained with $0.25 \%$ cresyl violet.

As a control for any potential effects of paraffin embedding, selected fetuses or postnatal hearts and blood vessels fixed in $4.0 \%$ paraformaldehyde were infiltrated with $25 \%$ sucrose, frozen, and sectioned in a cryostat. Slide-mounted sections were then prepared for in situ hybridization in parallel with the paraffin sections. The pattern of neurotrophin hybridization within the embryonic and postnatal cardiovascular system did not differ in paraffin and frozen sections.

SI nuclease protection assays. SI nuclease protection assays with the same probes were used to determine the relative amounts of mRNAs encoding each neurotrophin within atrial and ventricular tissue of the adult heart and provided evidence for a lack of cross-reactivity of the three neurotrophin probes. Hearts were dissected to obtain samples from the atria and upper, middle, and lower regions of the ventricle. Care 

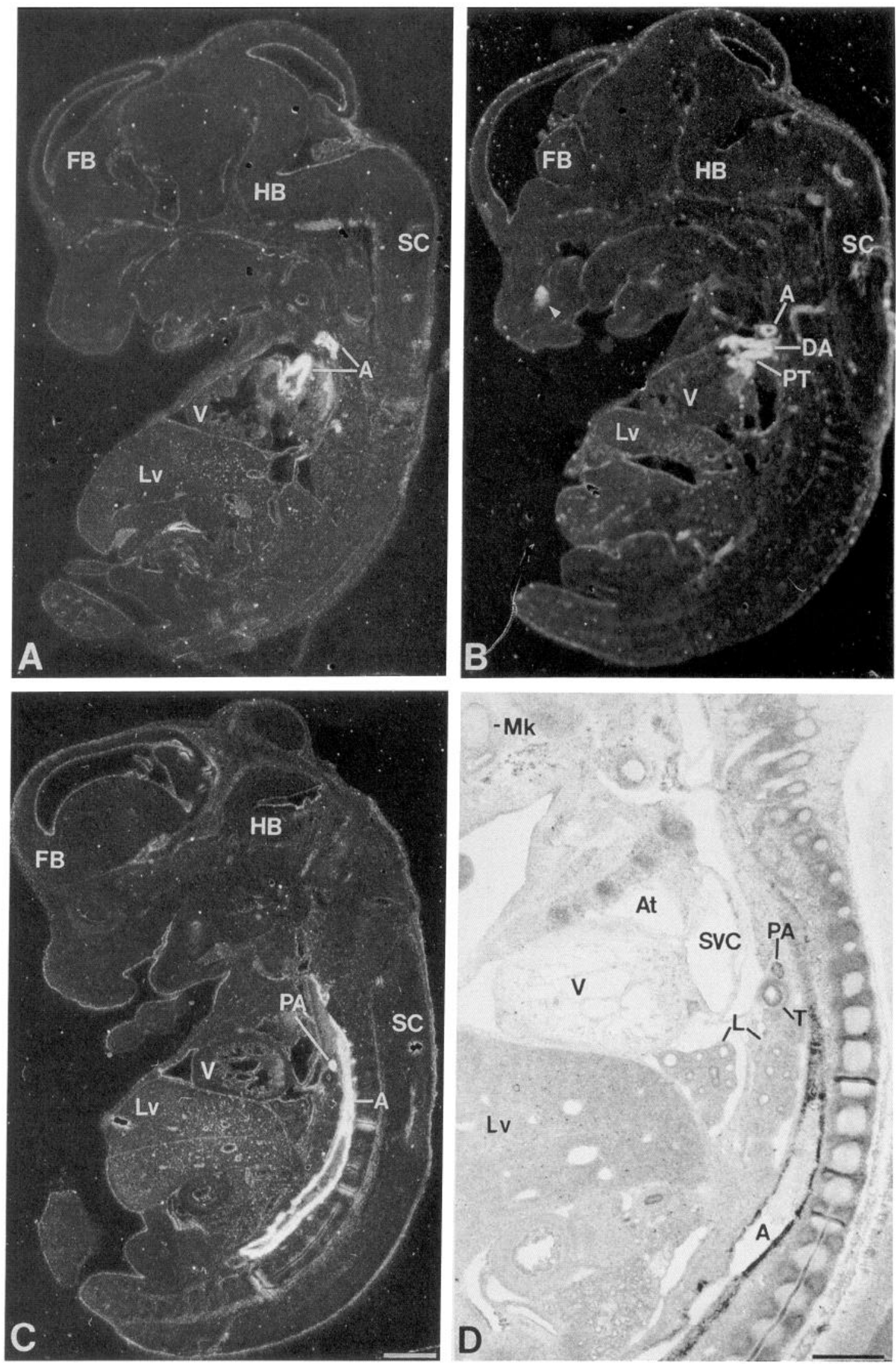

Figure 1. Autoradiographs showing the localization of NT-3 cRNA probe hybridization in sagittal sections through an E15 rat fetus. This is typical of the localization and extent of hybridization with NGF, BDNF, and NT-3 at this age. $A-C$ are dark-field photomicrographs in medial to lateral order. $D$ is a bright-field photomicrograph of the same section shown in dark field in $C$. The densest label appears in the aorta $(A)$, pulmonary trunk $(P T)$, and ductus arteriosus $(D A)$. No significant hybridization is seen within the atria $(A t)$ or ventricles $(V)$ of the heart, or in the liver $(L v)$, lung $(L)$, vena cava, or CNS. Arrowhead in $B$ indicates hybridization in the vomeronasal cartilage. $F B$, forebrain; $H B$, hindbrain; $M k$, Meckel's cartilage; $P A$, pulmonary artery; $S C$, spinal cord; $S V C$, superior vena cava; $T$, trachea. Scale bars: $A-C, 1.0 \mathrm{~mm} ; D, 0.5 \mathrm{~mm}$. 

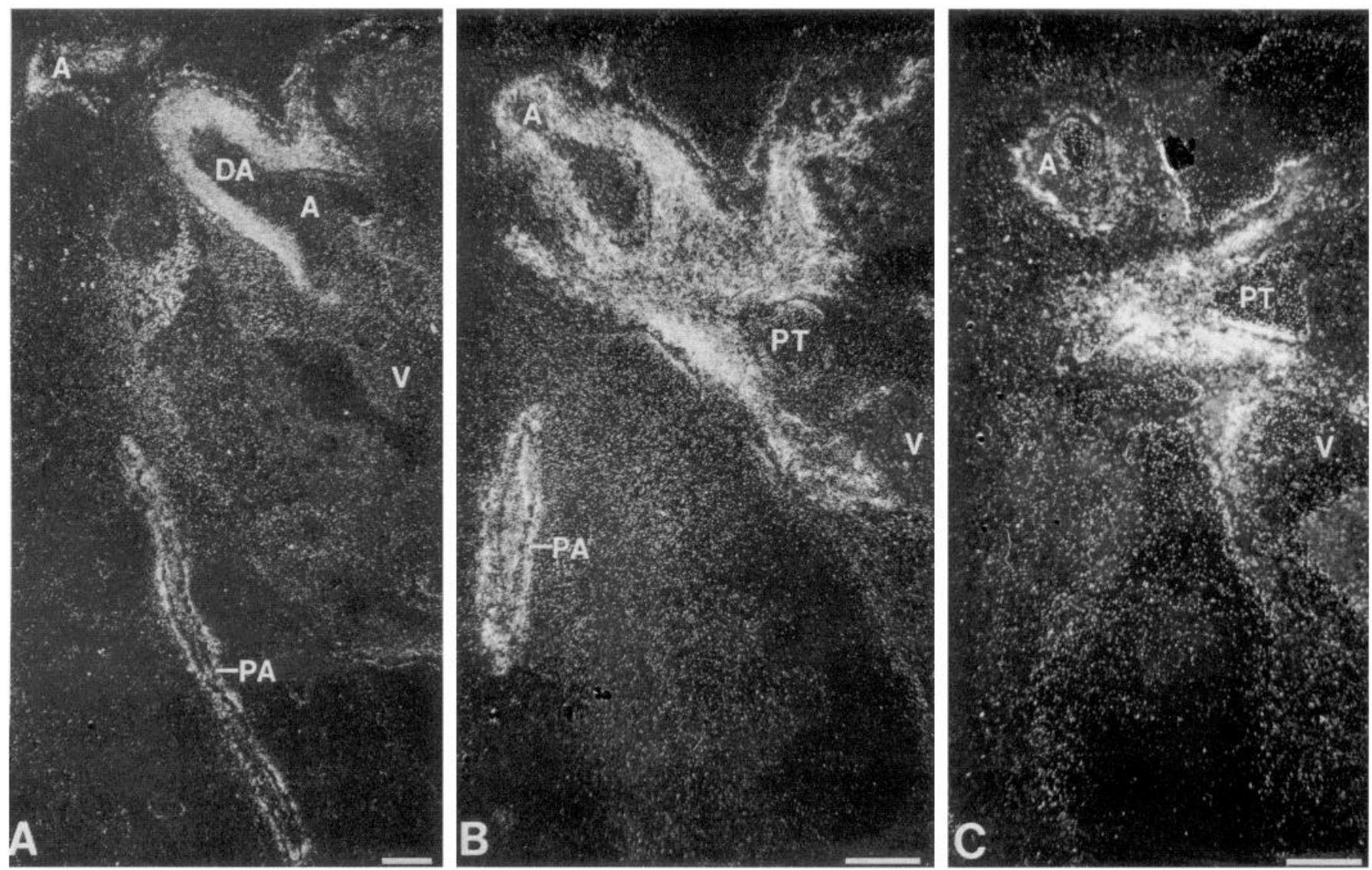

Figure 2. Dark-field photomicrographs from a sagittal series of the same embryo at E15 showing NGF $(A)$, NT-3 $(B)$, and BDNF $(C)$ probe hybridization. Intense hybridization is seen within the developing tunica media of the aorta $(A)$, pulmonary trunk $(P T)$, and ductus arteriosus $(D A)$. Labeling is also found within the pulmonary artery $(P A)$ and at the roots of the vessels arising from the heart, but the rest of the wall of the ventricles $(V)$ and the developing lung are unlabeled. Scale bars, $100 \mu \mathrm{m}$.

was taken not to include the origins of the aorta and pulmonary artery or the semilunar valves in samples of the lower ventricle. Total cellular RNA was isolated by guanidine thiocyanate extraction (Chirgwin et al., 1979). Probes for S1 nuclease protection experiments were designed to be shorter than those used for in situ hybridization to avoid background produced by incompletely synthesized transcripts. For NT-3, a 440 base antisense RNA probe was transcribed from PvulI-linearized pR150-1, which contains a 340 base pair insert corresponding to the coding region of amino acids 3-115 of mature rat NT-3 (Maisonpierre et al., 1990a). The antisense BDNF RNA probe was transcribed from NcoI-linearized pR1112-8, which produces a 225 base probe containing 180 bases complementary to rat BDNF mRNA. Control $\mathrm{S} 1$ nuclease protection assays were performed with the cyclophilin probe used for the in situ hybridization experiments and with a 300 base probe corresponding to bases 2048-2345 of the H-ras oncogene T24 genomic clone (Reddy, 1983), which contains 180 bases complementary to the second exon of $\mathrm{H}$-ras mRNA. Ten micrograms of total RNA extracted from the aorta and various regions of the heart were hybridized to the aforementioned ${ }^{32} \mathrm{P}$ labeled RNA probes, digested with S1 nuclease, and fractionated by $6 \%$ polyacrylamide, $7 \mathrm{M}$ urea gel electrophoresis (Gall and Isackson, 1989). Gels were exposed to Kodak XAR 5 film for $24-48 \mathrm{hr}$.

Probe specificity. The specificity and lack of cross-reactivity between the probes under the hybridization conditions used in this study were demonstrated by comparison of hybridization obtained in adjacent sec- tions hybridized to antisense- and to control, sense-strand NGF, BDNF, and NT-3 cRNAs. Patterns of hybridization with cRNA probes for the low-molecular- weight NGF-R and cyclophilin mRNAs were examined in other series of sections from the same animals as further controls. In addition, ${ }^{32} \mathrm{P}$-labeled BDNF and NT-3 cRNA probes failed to produce detectable signal following hybridization with male mouse submandibular gland RNA, which contains very high levels of NGF mRNA (not shown). Similarly, NGF and BDNF cRNA probes did not produce detectable signal in $\mathrm{S} 1$ nuclease protection assays with a nonradioactive sense-strand NT-3 cRNA control probe (not shown).

Localization of HNK-1 and NCAM immunoreactivity. In selected embryos at all ages from E12 to E18, series of sections alternating with those prepared for in situ hybridization were mounted and stained immunocytochemically for neural cell adhesion molecule (NCAM; Raphael et al., 1988) or with the HNK-1 antibody (Vincent and Thiery, 1984; Bronner-Fraser, 1986). Other series of similarly prepared transverse or sagittal sections were obtained from E10-E18 embryos and stained in the same manner. NCAM was detected using a polyclonal rabbit antiserum raised against the adult form of mouse NCAM (gift from G. M. Edelman, \#569; Raphael et al., 1988), diluted 1:250. The HNK-1 antigen was localized using a mouse monoclonal antibody to human lymphocyte HNK-1 antigen (anti-LEU-7, Becton-Dickinson, diluted 1:40). In each case, the slide-mounted sections were preincubated in a solution of $0.1 \mathrm{M}$ phosphate buffer, $0.3 \%$ Triton X-100, and

Figure 3. Bright-field photomicrographs showing NGF $(A, C), \operatorname{BDNF}(B)$, and NT-3 $(D)$ probe hybridization in sagittal sections from a series through the thoracic region of the same E15 embryo. All significant hybridization is confined to the developing tunica media (open arrows) and subendothelial layer (solid arrows) of the pulmonary trunk $(P T)$, pulmonary artery $(P A)$, and aorta $(A)$. The only significant label in the walls of the ventricles $(V)$ is deep to the valve cushions at the origins of the aorta and pulmonary trunk (arrowheads in $D$ ). No hybridization above background is seen within the bronchi $(B)$ or parenchyma of the developing lung. Scale bars: $A$ and $D, 100 \mu \mathrm{m} ; B$ and $C, 50 \mu \mathrm{m}$. 


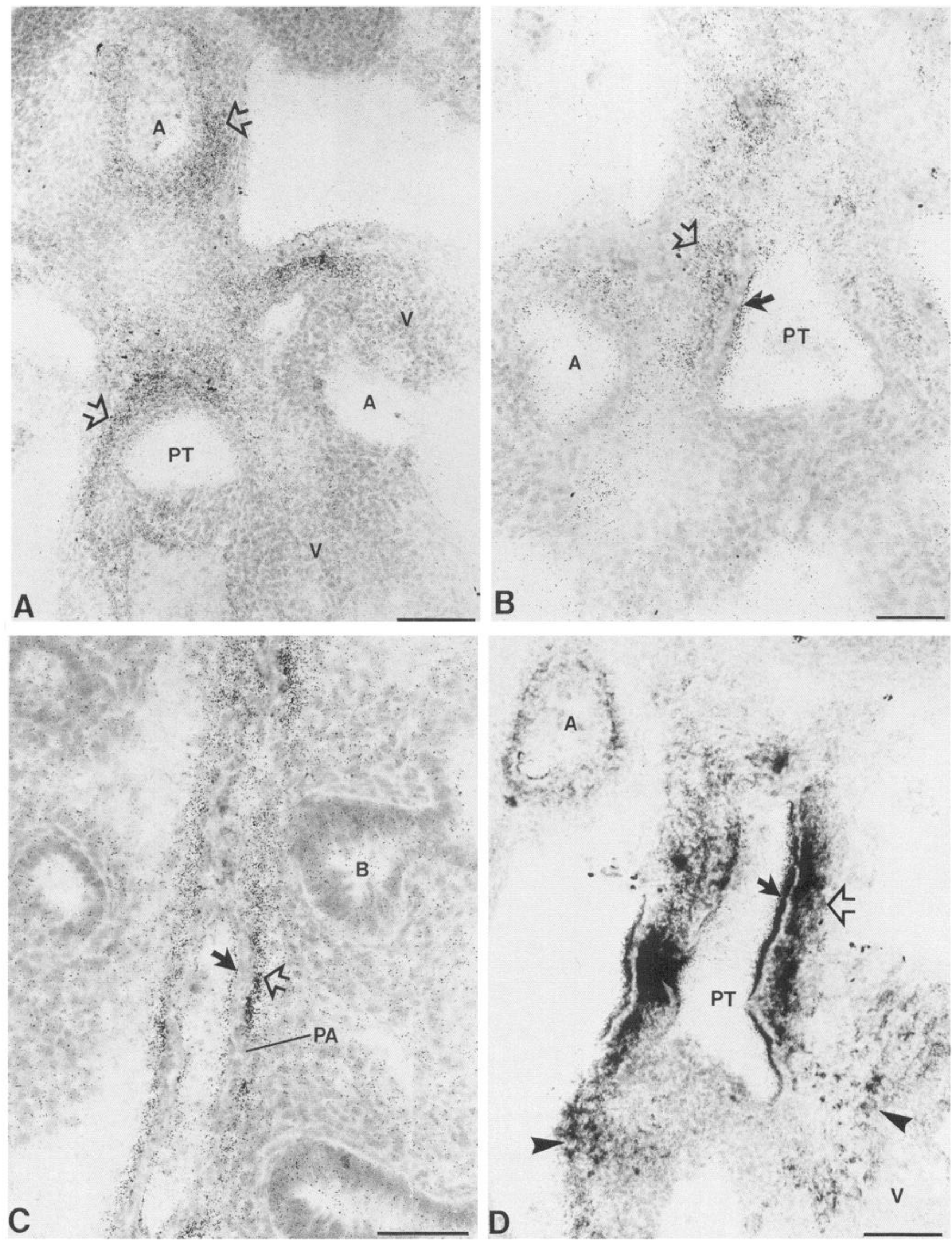



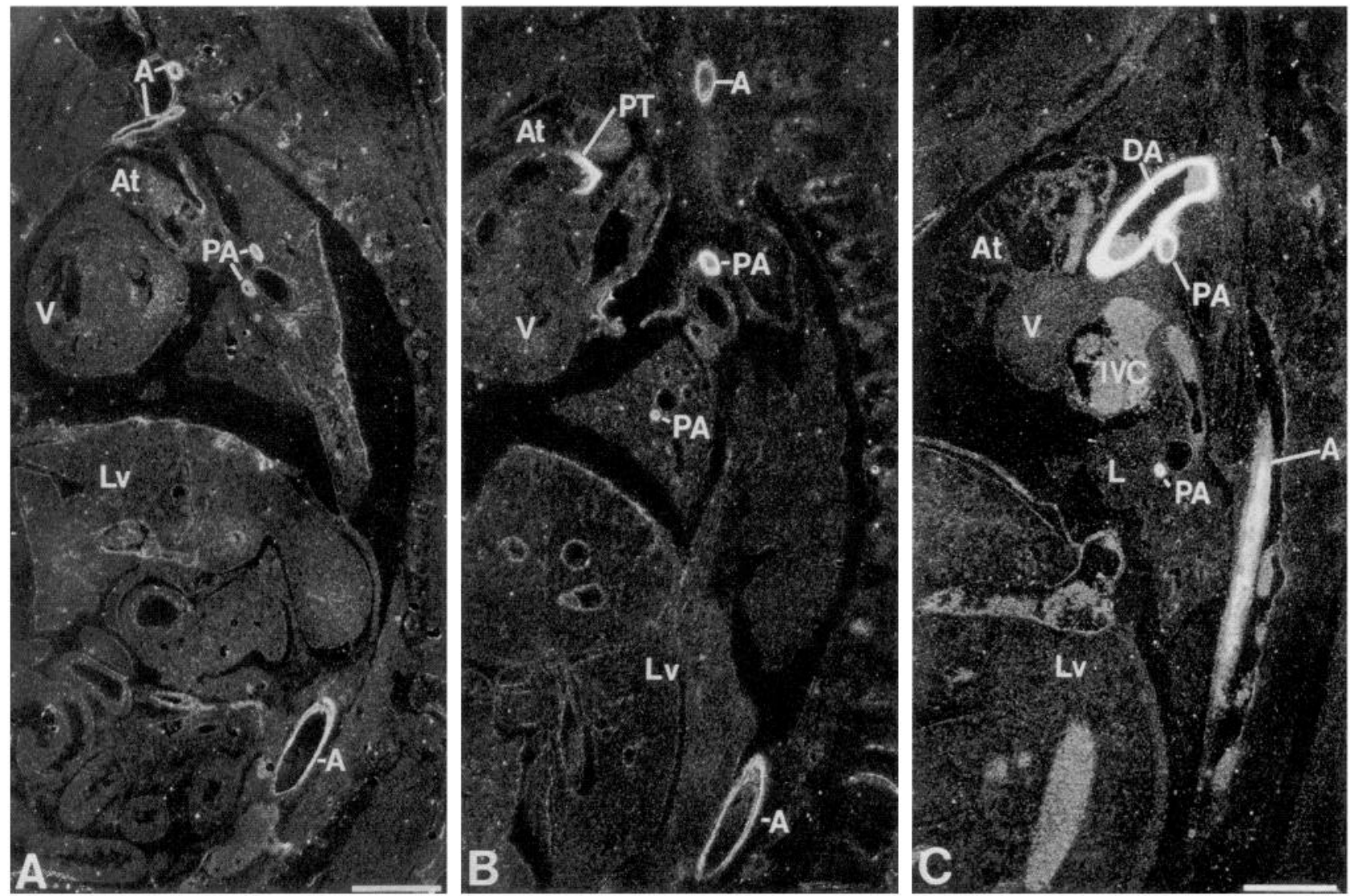

Figure 4. Dark-field photomicrographs showing localization of NGF $(A)$, NT-3 $(B)$, and BDNF $(C)$ probe hybridization in sequential sagittal sections from a series through the same E18 embryo. Levels of BDNF and NT-3 hybridization are approximately equal, but NGF cRNA probe hybridization is somewhat less compared to NT-3 and BDNF and to NGF hybridization on E15. No significant hybridization is seen within the walls of the atria $(A t)$, ventricles $(V)$, or inferior vena cava $(I V C$, in $C)$. $A$, aorta; $L$, lung; $L v$, liver; $P A$, pulmonary artery; $P T$, pulmonary trunk; $D A$, ductus arteriosus. Scale bars, $1 \mathrm{~mm}$.

$3 \%$ normal swine serum. The primary antiserum or antibody was diluted in the preincubation solution and applied for a period of $24 \mathrm{hr}$ at $4^{\circ} \mathrm{C}$. Sections were then reacted by the avidin-biotin-peroxidase technique using ABC kits (Vectastain), counterstained with thionin, dehydrated, cleared, and coverslipped. Control sections were stained without including the primary. These revealed no specific staining.

\section{Results}

Expression of NGF, BDNF, and NT-3 mRNAs in the developing cardiovascular system

Hybridization of probes to all three neurotrophins is first weakly detected in thoracic and abdominal regions of E13 fetuses, but labeling rises to very intense levels by E15. Thereafter, probe hybridization is found at high levels at all fetal ages examined and in newborn and adult animals (Figs. 1-6). Figure 1, showing hybridization of the NT-3 riboprobe, is indicative of the maximal extent of labeling with all three probes and representative of the appearances seen from E15 to birth.

At all fetal ages examined, all significant neurotrophin probe hybridization in the thorax and abdomen is confined to the walls of the large elastic arteries (Fig. 1). When fully established, from E15 on, the densest label by far occurs in the aorta, main pulmonary trunk, and ductus arteriosus and continues at a lesser intensity into the principal branches of the aorta and pulmonary trunk (Figs. 1, 2). The only significant label in the heart is found in the part of the ventricular wall immediately deep to the aortic and pulmonary valves, and is generally light in comparison with that in the vessel walls (Figs. 2, 3). Hybridization quickly becomes extremely dense, however, as it extends from the bases of the two valves into the walls of the arch of the aorta and pulmonary trunk and into the ductus arteriosus. Dense label continues from the aortic arch and ductus arteriosus down the length of the descending thoracic and abdominal aorta, ending abruptly at the point of branching into the common iliac arteries (Fig. 1). Relatively less intense label extends from the aortic arch into the walls of the left subclavian, left common carotid, and brachiocephalic arteries, but in most preparations becomes reduced to background levels at approximately the point at which their first branches are given off. In most preparations, no branches of the abdominal aorta show significant labeling (Figs. $1,4)$. In sections in which labeling overall is unusually high, however, light labeling continues into the walls of the internal thoracic and celiac arteries for a short distance. In all preparations, labeling in the pulmonary trunk continues at slightly reduced levels into the left and right pulmonary arteries and from these into the principal lobar branches of these vessels but not into the next generation of branches (Figs. 2-4). No labeling above background is seen in the adjacent developing bronchi, or in the liver, gut, kidney, or other developing visceral structures (see Figs. 1, 4).

Over time, the relative intensity of labeling with each probe varies. At E15 the most intense labeling is seen with riboprobes for NT-3 mRNA (Figs. 1, 2). NGF probe hybridization, while 

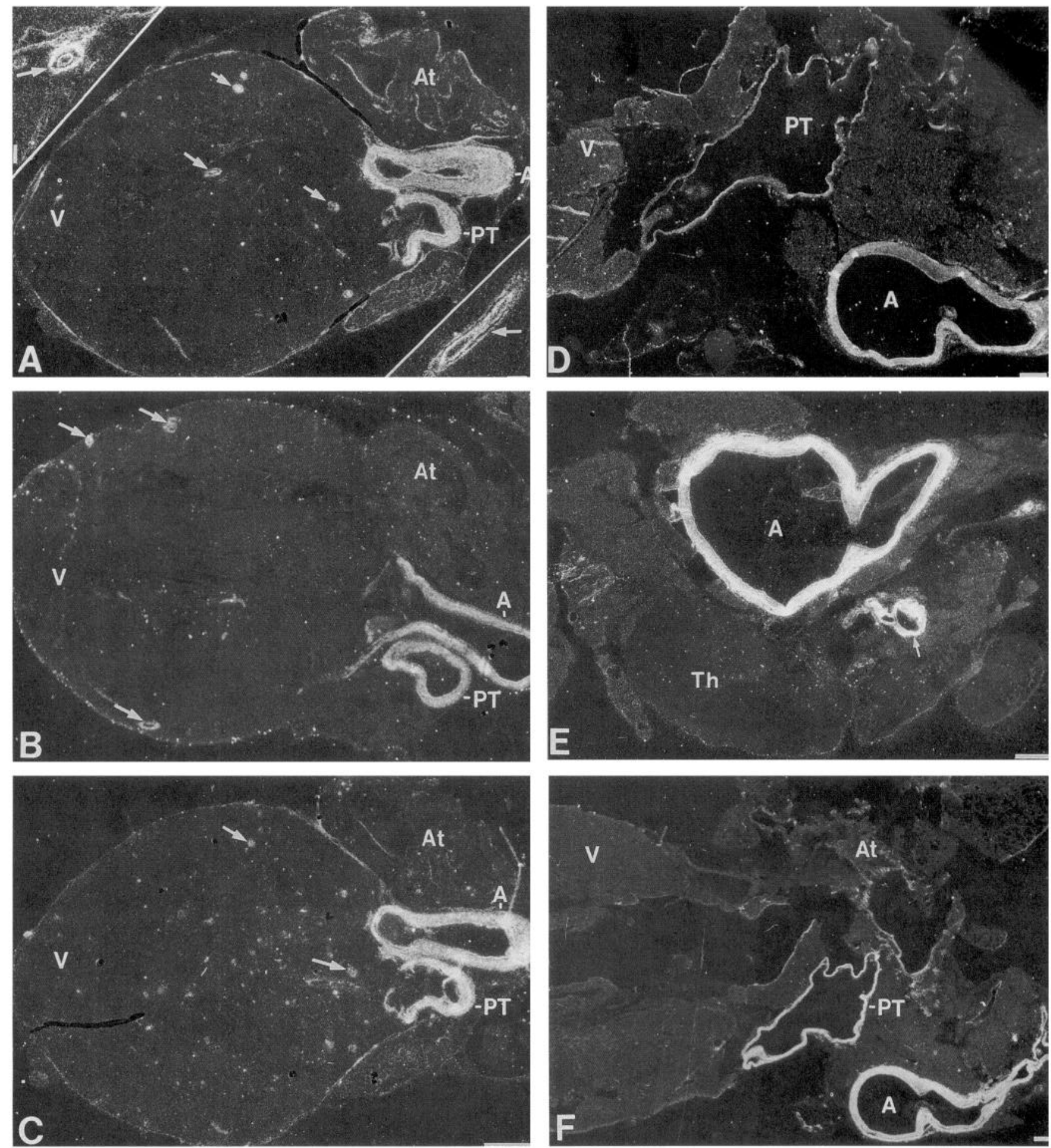

Figure 5. Dark-field photomicrographs of sections through a P0 $(A-C)$ and an adult $(D-F)$ rat heart hybridized with NGF $(A, D)$, BDNF $(B, E)$, or NT-3 $(C, F)$ cRNA probes. At P0, the walls of the pulmonary trunk $(P T)$ and aorta $(A)$ continue to express high levels of NGF, BDNF, and NT-3 mRNA, and hybridization of all three neurotrophin probes appears in the coronary arteries (arrows in $A-C$ and insets in $A$ ). In the adult, NGF probe hybridization is significantly reduced $(D)$, but BDNF $(E)$ and NT-3 $(F)$ probe hybridization remains extremely robust within the aorta, its main branches (arrows), and in the pulmonary trunk. At both P0 and in the adult, probe hybridization remains absent from the atria $(A t)$ and ventricles $(V)$. Th, thymus. Scale bars, $A-F, 0.5 \mathrm{~mm}$; insets in $A, 10 \mu \mathrm{m}$.

less than that for NT-3 mRNAs, is in most regions greater than that for BDNF mRNA (Figs. 2, 3). By E18, however, BDNF probe hybridization has increased to levels comparable to that for NT-3 while NGF probe hybridization has decreased some- what (Fig. 4). At birth, hybridization is intense with all three riboprobes. In newborn and adult animals, the only significant difference in the distribution of labeling is that label can now be detected in the walls of the coronary arteries (Fig. 5). In adults, 

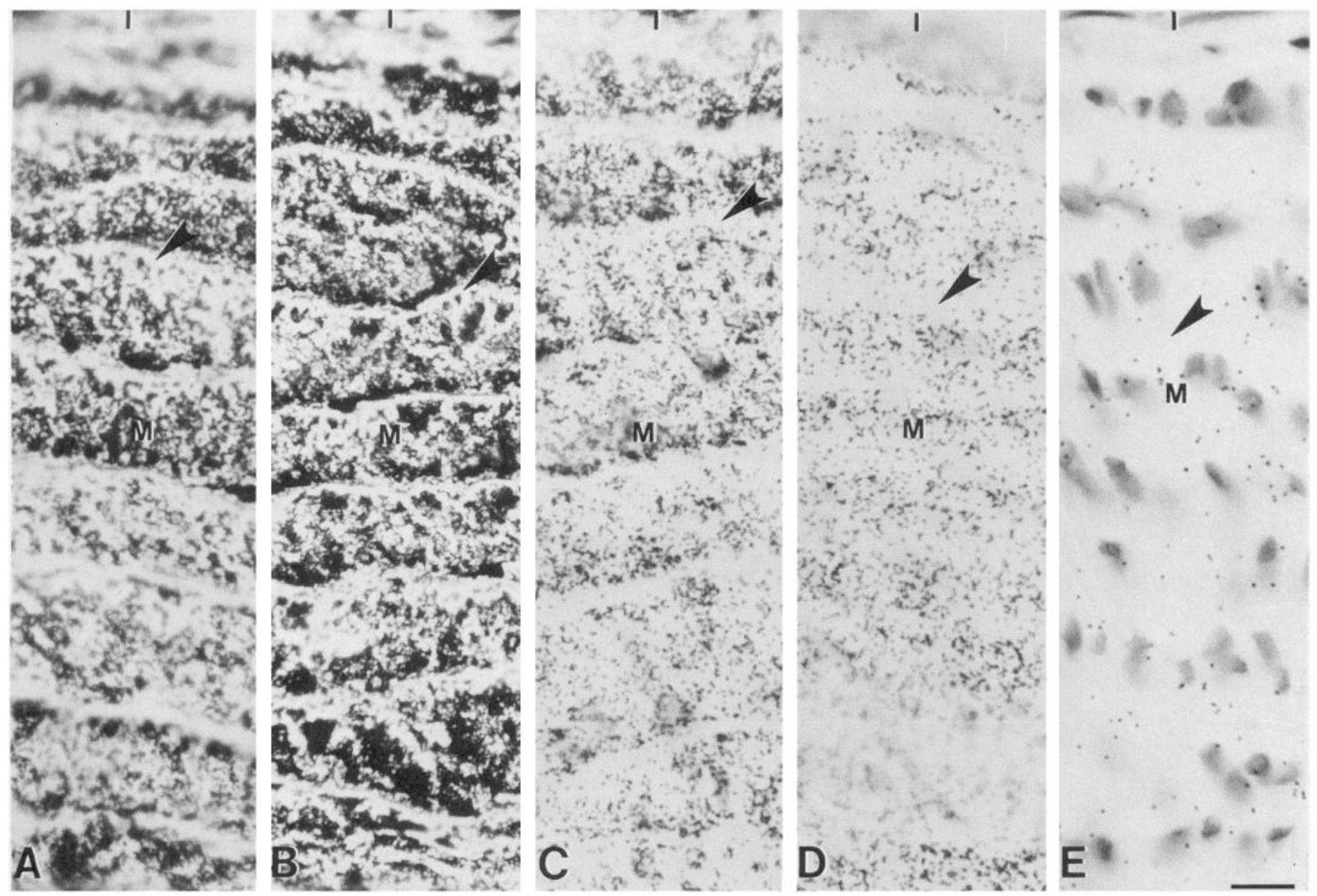

Figure 6. $A-C$, Bright-field photomicrographs showing NT-3 $(A), \operatorname{BDNF}(B)$, and NGF $(C)$ probe hybridization in the wall of the adult aorta. In each case, hybridization is largely confined to the tunica media $(M)$, where it is coextensive with the laminae of smooth muscle cells. The intervening elastic laminae, one of which is shown at arrowhead in each case, do not show hybridization of antisense cRNA probes. Hybridization can also be detected within the tunica intima $(I)$. The levels of NT-3 $(A)$ and BDNF $(B)$ probe hybridization remain high but NGF $(C)$ hybridization is reduced relative to that observed at earlier stages of development. $D$ and $E$, Examples of specificity controls for the in situ hybridization histochemistry. $D$ shows cyclophilin cRNA hybridization localized within the walls of the adult aorta. Hybridization of BDNF $(E)$, NGF, and NT-3 sense probes produces only background labeling. Larger profiles in $E$ are nuclei of smooth muscle cells that are obscured by dense labeling in $A-D$. Scale bar, $10 \mu \mathrm{m}$.

BDNF and NT-3 hybridization is of equal density while hybridization with the NGF riboprobe has decreased significantly (Figs. 5, 6).

In the walls of the aorta, pulmonary trunk, ductus arteriosus, and of the major branches of the first two, label is heaviest over and largely confined to the developing tunica media (Figs. 2, 3, 6). At E13-E18, the labeled cells are mostly round or ovoid and do not display the flattened appearance of smooth muscle cells of the tunica media in arteries of adults. The elastic laminae of the vessels are not detectable up to and including E18, at least with the counterstaining technique used (Figs. 2, 4). A thin layer of slightly less intense labeling is associated with the endothelium and/or the immediate subendothelial layer (Fig. 3), and a thin, relatively clear layer commonly intervenes between this and the dense labeling of the developing tunica media. The internal layer of labeling is generally heaviest with NT-3 probes (Fig. 3). In the arterial walls of the newborn and adult animals, distinct concentric layers of elastic fibers alternating with smooth muscle cells can be identified in the tunica media, and it is clear that labeling with all three riboprobes lies over smooth muscle cells and not over the elastic laminae (Fig. 6). The subendothelial layer of label is less distinct at these ages. The adventitial layer of the vessels displays very light or no labeling in the fetus or newborn, but moderate levels of label can often be detected in adult animals (Fig. 6).

In the developing heart at all ages examined, the only significant labeling with all three probes is in the walls of the aorta and pulmonary trunk deep to the cusps of the aortic and pulmonary valves, at the points at which the two arteries emerge from the left and right ventricles (Figs. 2, 3). There is little or no labeling within the coronary vessels at fetal ages. Label within the walls of the coronary vessels becomes relatively dense in P0 hearts but declines again in adult hearts (Fig. 5). In newborn, fetal, and adult hearts, no significant labeling can be detected in the walls of the atria and ventricles with the exposure times used (Figs. 1-5). The walls of the superior and inferior vena cava and of the pulmonary veins are also devoid of label at their point of entry into the heart and along their full lengths in fetal, newborn, and adult animals. In contrast to neurotrophin probe hybridization, hybridization of a probe to cyclophilin, a protein expressed in virtually all cells, is intense over the muscle layer of the atria and ventricles as well as in the walls of the great 


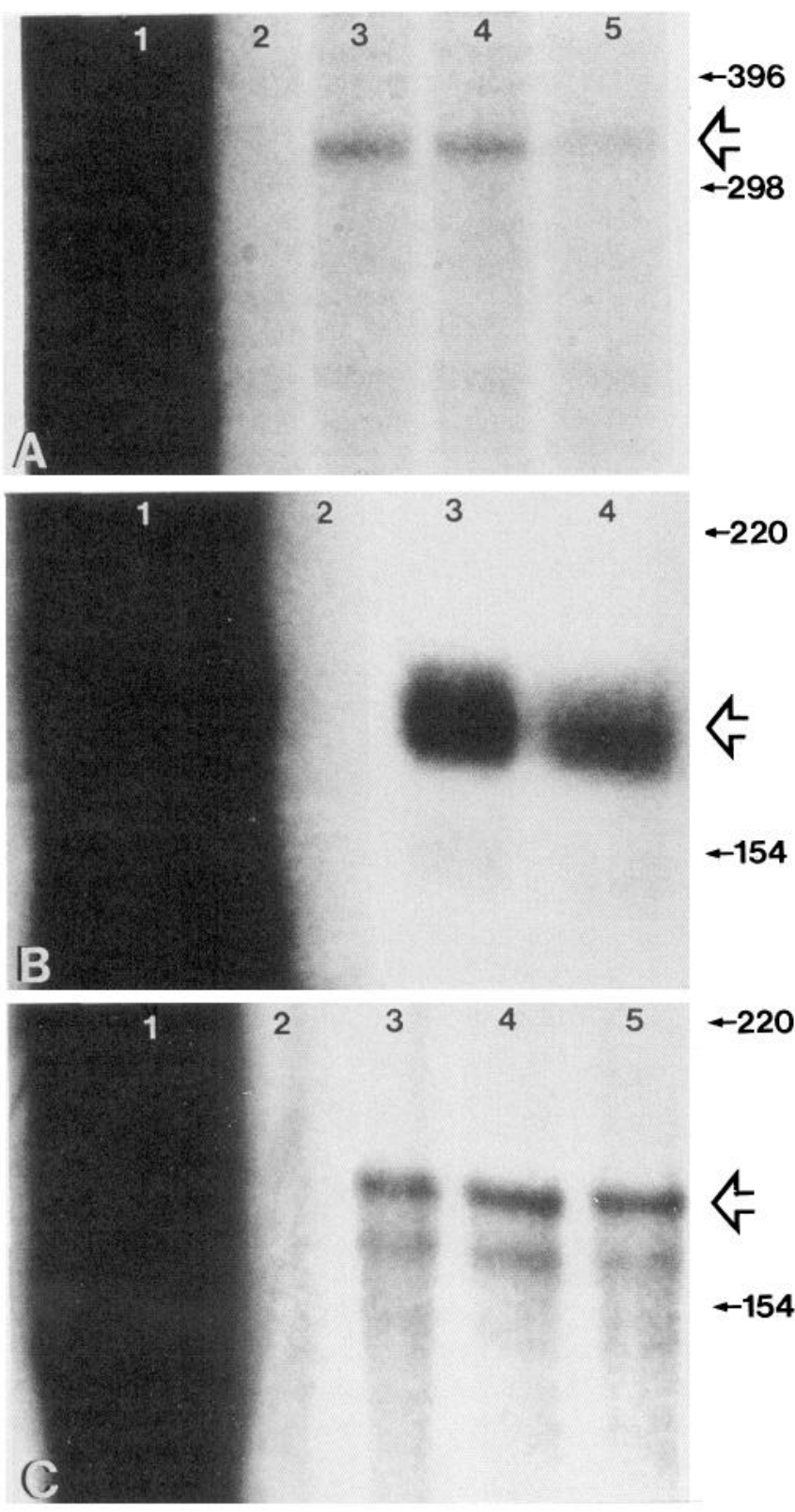

Figure 7. S1 nuclease protection assays showing levels of NT-3 $(A)$, BDNF $(B)$, and $\mathrm{H}$-ras $(C)$ mRNAs in samples of total RNA obtained from different regions of the same adult heart. In $A-C$, lane $l$ contains cRNA probe without S1 nuclease digestion and lane 2 contains S1digested probe protected with wheat germ tRNA alone. The remaining lanes contain cRNA probe protected by RNA from various heart samples. $A$, Protection of NT-3 cRNA probe. Lane 3,10 $\mu \mathrm{g}$ of total RNA from the atria, including portions of the aorta and pulmonary trunk; lane 4, upper ventricle, including bases of aorta and pulmonary trunk; lane 5, ventricles dissected free of the origins of the aorta and pulmonary trunk. Low level of protected probe in lane 5 probably reflects expression of NT-3 in coronary arteries. B, Protection of BDNF cRNA probe. Lane $3,10 \mu \mathrm{g}$ of total RNA from the upper one-third of the ventricle and including origins of aorta and pulmonary trunk; lane 4, ventricles dissected free of the origins of the aorta and pulmonary trunk, but still containing coronary arteries that may account for remaining signal. $C$, Protection of $\mathrm{H}$-ras cRNA probe. Lane 3, $5 \mu \mathrm{g}$ of total RNA from atria; lane 4, upper ventricle; lane 5, ventricles dissected free of the origins of the aorta and pulmonary trunk. Similar levels of $\mathrm{H}$-ras cRNA are protected by RNA from all regions of the heart examined. Size markers, indicated by solid arrows at far right, were ${ }^{32} \mathrm{P}$-labeled Hinfl-digested pBR322 fragments. Protected fragments (open arrows) are approximately 340 base pairs in $A$ and 180 base pairs in $B$ and $C$. These are vessels at all ages (Fig. 6D). Hybridization with sense control riboprobes produced no label above background in any of these structures at any age (Fig. $6 E$ ).

The high expression of neurotrophin mRNA seen in arterial tissue with in situ hybridization was confirmed by the S1 nuclease protection assays (Fig. 7). In heart samples, significantly more neurotrophin mRNA was detected in samples of the atria and upper one-third of the ventricles, which could not be freed of arterial tissue, compared with samples taken from the lower parts of the ventricles, which could be dissected free of the points of origin of the aorta and pulmonary trunk although not of the contained coronary arteries. The presence of the latter may account for the modest levels of neurotrophin mRNA detected by $\mathrm{S} 1$ nuclease protection assays. By contrast, the same samples of heart mRNA protected similar levels of the H-ras probe, which encodes a ubiquitously expressed protein.

\section{Early expression of neurotrophin $M R N A s$ and relation to innervation of the developing cardiovascular system}

Earliest appearance of hybridization. For all three riboprobes, there is no labeling in E12 fetuses. Probe hybridization is first detected in the walls of the great vessels on E13 (Fig. 8). Thereafter, the density of hybridization of each riboprobe progressively increases. The highest hybridization signal with the NGF and NT-3 riboprobes during the embryonic period is obtained on E15 (Figs. 1-3). With the BDNF probe, signal appears maximal at E18 (Figs. 4).

A fine meshwork of NCAM-immunoreactive nerve fascicles (Figs. 8,9) is found in the walls of the heart and larger blood vessels of the trunk from E12, and at later ages is coextensive with the in situ hybridization for the mRNA encoding the three neurotrophins. These immunostained fibers are detectable at E12, before probe hybridization can be detected, but become much more obvious at E13 when hybridization first becomes apparent (Fig. 8). The entire length of the wall of the aorta is permeated in the regions of probe localization by fine NCAMimmunoreactive fibers derived from the adjoining sympathetic trunks (Figs. 8, 9).

Appearance of HNK-1-immunoreactive cells and NCAM-immunoreactive fibers. The HNK-1 antibody stains certain parts of the wall of the developing and postnatal heart (Figs. 10,11A). HNK-1 staining generally overlaps but is not coextensive with NCAM immunoreactivity, which is more widely distributed within the developing heart (Fig. 9). HNK-1 staining is most extensive from E14 onward but can be detected in the same general region from E10. In the older embryos the staining reveals interconnected bundles of immunoreactive fibers with interspersed cell somata (Fig. I0). The principal concentrations of HNK-1 cell and fiber staining within the heart are in the walls of the superior and inferior vena cava as these enter the right atrium, in posterior parts of the right atrial wall, and in the ventricular wall in the region of the atrioventricular sulcus. The relative positions of these concentrations suggest their association with the sinuatrial and atrioventricular nodes. Numerous cells within the trabeculae carneae and papillary muscles of the ventricular wall are also HNK-1 immunoreactive, and a variable number of HNK-1-immunoreactive cells can be identified at the bases of the atrioventricular, aortic, and pulmonary valves

the predicted sizes of the protected regions of the NT-3, BDNF, and $\mathrm{H}$-ras cRNA probes. 

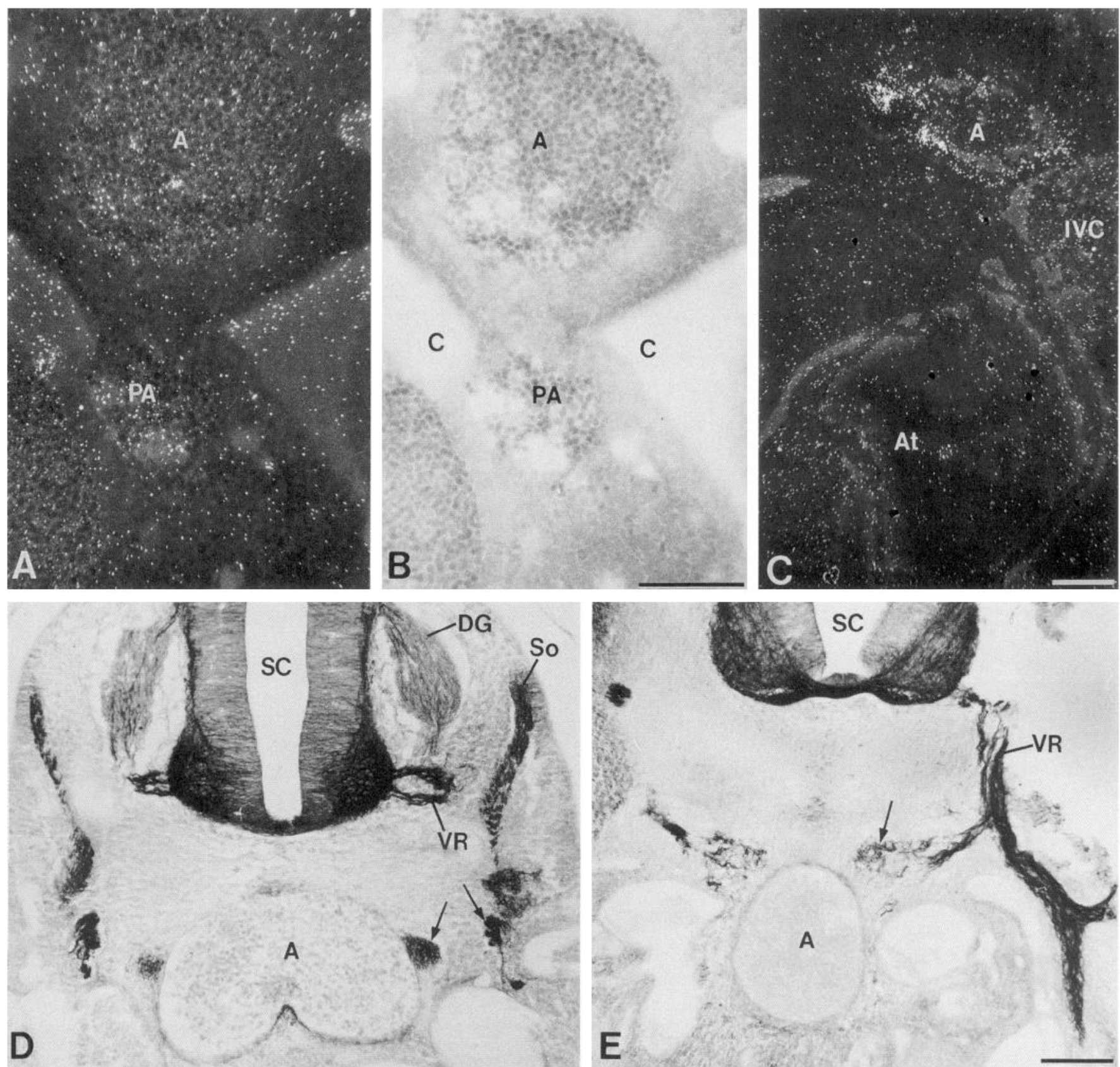

Figure 8. $A$ and $B$, Paired dark-field $(A)$ and bright-field $(B)$ photomicrographs of a transverse section through an E12 embryo showing a lack of BDNF probe hybridization in the aorta $(A)$ and pulmonary artery $(P A)$ at this age. $C$, Dark-field photomicrograph of a sagittal section through the comparable region of an E13 embryo showing low levels of BDNF probe hybridization in the wall of the aorta. $D$ and $E$, NCAM immunoreactivity in transverse sections at the level of the abdominal aorta on E12 $(D)$ and E13 $(E)$ showing NCAM-immunoreactive sympathetic ganglion cells and fibers (arrows) contributing to the aortic plexus at these ages. $A t$, atrium; $C$, coelom; $D G$, dorsal root ganglion; $I V C$, inferior vena cava; $S C$, spinal cord; So, somite; $V R$, ventral root. Scale bars, $100 \mu \mathrm{m}$.

(Fig. 10B). None of these regions of HNK-1 staining show significant riboprobe hybridization during embryonic development, except for the bases of the pulmonary and aortic valves, which are regions of less intense probe hybridization (Figs. 2, 3,11 ). HNK-1-immunoreactive cells and fibers can also be identified in the walls of the aorta, pulmonary trunk, and ductus arteriosus in fetuses from E14 onward, the fibers showing a distribution similar to that revealed by NCAM immunoreactivity.

The superior, middle, and inferior cervical ganglia and many of the segmental ganglia of the thoracoabdominal sympathetic chain can be detected as condensations of large, relatively darkly staining neurons in thionin-stained sections and by immunoreactive staining with the HNK-1 antibody and NCAM antiserum (Figs. 9, 11). HNK-1 also stains a proportion of the cells in the dorsal root ganglia and in the root ganglia of the cranial nerves, as well as the spinal nerve roots, rami communicantes, and intersegmental trunks of the sympathetic chain, and certain branches of the vagus in the head and thorax (Fig. 11). All of these are also stained intensely for NCAM immunoreactivity (Figs. 8,9), which gives a very clear picture in the thorax and abdomen of the cardiac, celiac, mesenteric, and other nerve 

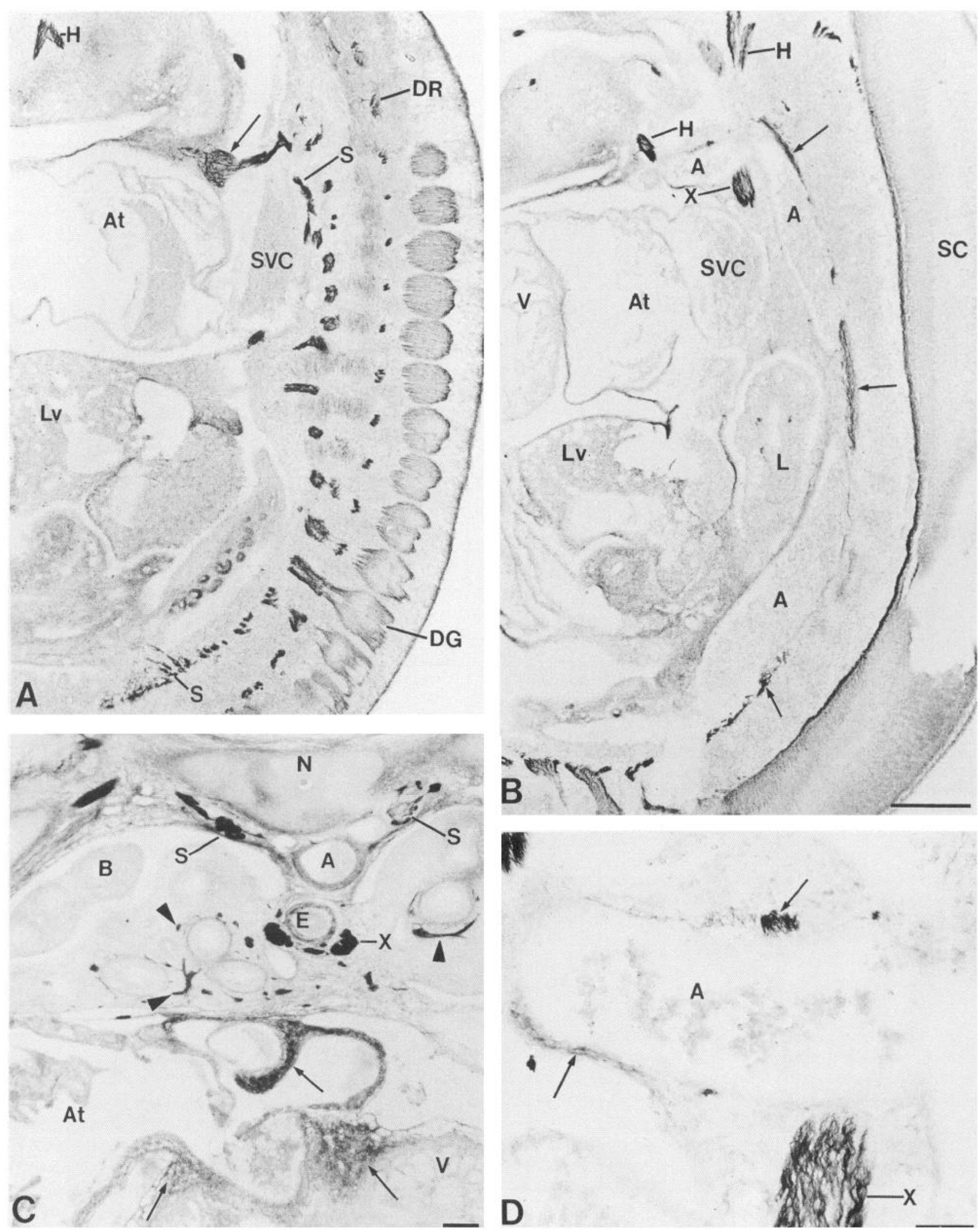

Figure 9. $A-D$ are bright-field photomicrographs showing immunostaining for NCAM on E15. In $A$, NCAM immunoreactivity outlines sympathetic chain $(S)$, dorsal spinal nerve roots $(D R)$, dorsal root ganglia $(D G)$, and fibers of the cardiac plexus (arrows in $A$ and $C$ ). In $B$, NCAM immunoreactivity reveals fibers derived from the sympathetic chain and found along the length of the aorta (arrows). Parts of the vagus $(X)$ and hypoglossal $(H)$ nerve are also visible. $C$, NCAM-immunoreactive nerve fibers (arrowheads) associated with the bronchi $(B)$ of the developing lung $(L)$. $D$, Highermagnification view of the arch of the aorta $(A)$ seen in $B$, showing extensive innervation of this vessel by NCAM-immunoreactive fibers (arrows) in the same region in which robust hybridization of NGF, BDNF, and NT-3 cRNA probes is found. $A t$, atria; $E$, esophagus; $L v$, liver; $N$, notochord; $S C$, spinal cord; $S V C$, superior vena cava; $V$, ventricle. Scale bars: $A$ and $B, 500 \mu \mathrm{m} ; C, 100 \mu \mathrm{m} ; D, 50 \mu \mathrm{m}$. 


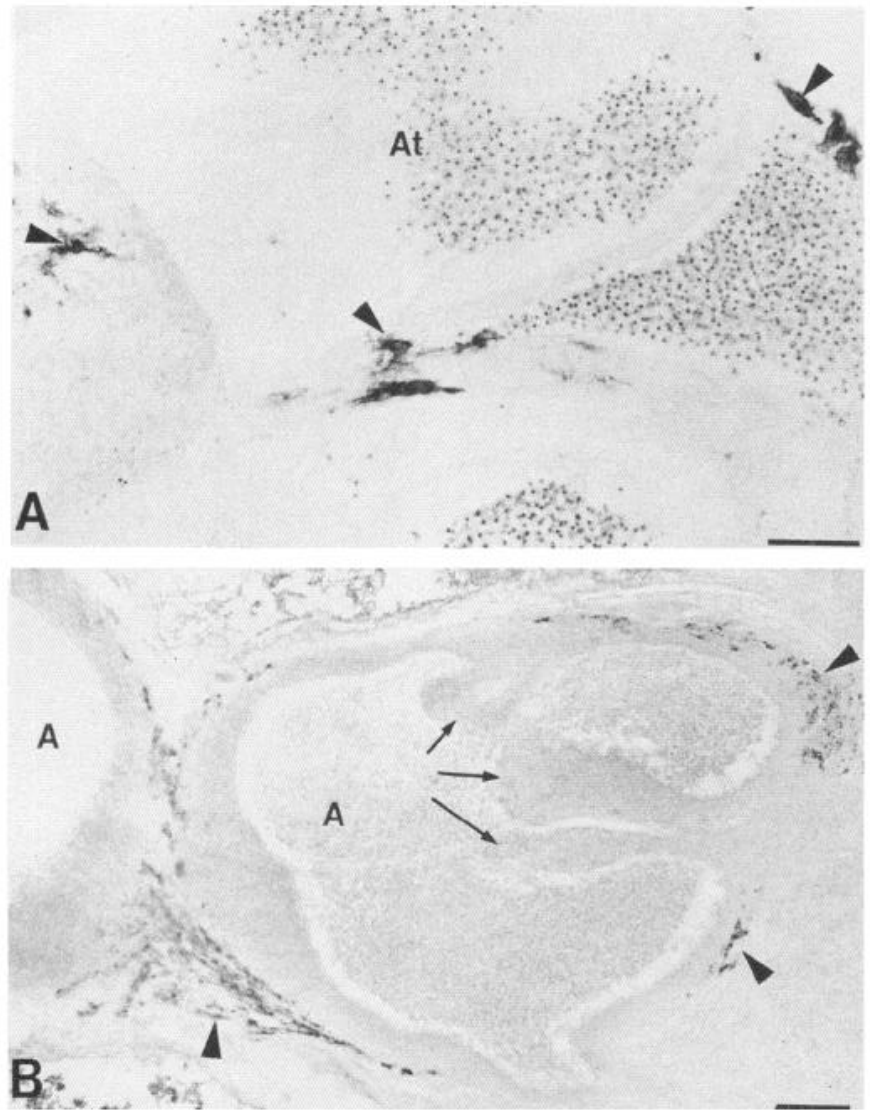

Figure 10. Bright-field photomicrographs showing immunostaining by the HNK-1 antibody on $\mathrm{E} 14(A)$ and $\mathrm{E} 18(B) . A, \mathrm{HNK}-1$-immunostained cell groups (arrowheads) within the walls of the atria $(A t)$, taken from region shown at low magnification in Figure $11 A$. $B$, Other HNK1-stained cell populations become increasingly obvious at the roots of the pulmonary trunk and aorta $(A)$ by E18 (arrowheads), and partially overlap regions of neurotrophin probe hybridization (see Figs. 1-4). Arrows $(B)$ indicate cusps of aortic valve. Scale bars, $50 \mu \mathrm{m}$.

plexuses as well as of the ganglia of the vagus and glossopharyngeal nerves. None of these structures show neurotrophin probe hybridization (Fig. 11).

\section{Expression of the low-molecular-weight $N G F-R$}

For comparative purposes, and further confirmation of the specificity of the neurotrophin probes, a cRNA probe to the lowmolecular-weight NGF-R was used for in situ hybridization histochemistry on selected embryos. The pattern of probe hybridization seen at E15 is representative (Fig. 12). In the cervical region, thorax, and abdomen, NGF-R probe localization outlines the principal nerve trunks of the cervical plexus and sympathetic chain, but no detectable hybridization occurs in the walls of the great vessels or the heart. In the head region, the trigeminal ganglion shows particularly dense labeling for NGF-R mRNA. The nodose and petrous ganglia show less heavy but distinct labeling. These ganglia are devoid of labeling following hybridization with the three neurotrophin mRNA probes.

\section{Expression of NGF, BDNF, and NT-3 in other regions of the developing embryo}

The only dense labeling found outside the cardiovascular system with the three neurotrophin probes in the E13-E18 fetuses is confined to various mesenchymal populations of the developing head, including the coats of the developing eye external to the pigment epithelium, cells surrounding Meckel's cartilage, the deep dermis of the developing mandibular arch, and the vomeronasal cartilage (Fig. 1). In each case, labeling is especially heavy with NT-3 probes. In embryonic sections with unusually high levels of label, the external sheaths of spinal nerves as they emerge from the intervertebral foramina and the pericranium are lightly labeled, especially with the NT-3 probe. No label with any probe is evident in derivatives of placodal tissue, including ganglia of cranial nerves and nerve trunks. Hybridization within the developing whisker pads of the maxillary and mandibular processes was not evident above background levels.

No significant labeling is seen in the brain or spinal cord at the embryonic ages examined and with the exposure times used (Fig. 1). Labeling is detected in the control brains of postnatal animals prepared in the same manner (Fig. 13). The time of appearance and distribution of hybridization follows that reported by others (Clegg et al., 1986; Friedman et al., 1991a,b). Dense NT-3 and light BDNF probe hybridization were seen in the cingulate cortex, hippocampal formation, and thalamus at P0. NGF probe hybridization does not appear above background levels at this age. At P7, NT-3 hybridization remains dense and both the NGF and BDNF riboprobes produce moderate levels of hybridization in the same regions.

No hybridization of the three neurotrophin probes can be detected in ganglia or trunks of the autonomic nervous system. Where the inferior cervical and stellate ganglia lie closely adjacent to the subclavian arteries, and the celiac ganglion to the abdominal aorta, radioactive label indicating hybridization of the three neurotrophin riboprobes in the arterial walls frequently lies closely adjacent to the ganglion cells (Fig. 11), but no ganglion cells are labeled. Label in the walls of the ascending aorta, aortic arch, pulmonary trunk, and ductus arteriosus is, similarly, close to but not obviously associated with the ganglion cells of the cardiac plexus (compare Figs. 1, 2, 9).

\section{Discussion}

These results demonstrate that mRNAs for the three neurotrophins NGF, BDNF, and NT-3 are coexpressed in the walls of the major thoracic and abdominal elastic arteries and their branches from the middle of fetal development to adulthood in the rat. They also reveal a striking lack of detectable expression over the same period in the thoracic and abdominal viscera, including the heart and the lungs, which, like the great vessels, receive substantial sympathetic and sensory innervation in the adult. The CNS of the fetus is similarly devoid of detectable expression by these methods. The great vessels are characterized by the appearance of a robust innervation early in development (Shaner, 1930; Kuntz, 1934; Gomez, 1958) and by the contribution they receive, at least in the chick, from cranial neural crest-derived ectomesenchyme (Le Lievre and Le Douarin, 1975; Kirby et al., 1983). Each of these factors may correlate with the precocious and profuse expression of neurotrophins within the great vessels.

\section{Spatial distribution of NGF, BDNF, and NT-3 mRNA within} the developing and adult cardiovascular system

In previous studies on adult animals, NGF, BDNF, and NT-3 $m R N A s$ have been demonstrated in a wide range of peripheral tissues, which include the heart and lungs (Hohn et al., 1990; 



Figure 11. Comparison of the distribution of HNK-1 immunoreactivity $(A)$ and NT-3 cRNA hybridization $(B)$ in adjacent sections at E14. NT-3 probe hybridization is confined to the wall of the aorta $(A)$ and to the ventricle $(V)$ in the vicinity of the aortic valve cushions $($ stars). HNK-1-stained cell groups (arrowheads) are seen within the walls of the atria $(A t)$ and at the right atrioventricular border (seen at higher magnification in Fig. 10A). Little or no neurotrophin hybridization is seen in these regions. $C$ and $D$, Probe hybridization for BDNF $(C)$ and NGF $(D)$, in adjacent sections through the same animal as $A$ and $B$. Hybridization is present in the aorta $(A)$ but is absent from the heart, inferior vena cava $(I V C)$, and stellate ganglion (arrows). The stellate ganglion is shown as an HNK-1-immunoreactive cell mass in $E$. Collections of dark dotted profiles in $A$ and $E$ are red blood cells. $L$, lung; $L v$, liver; $V$, ventricle; $X$, vagus. Scale bars: $A$ and $B, 200 \mu \mathrm{m} ; C, D$, and $E, 100 \mu \mathrm{m}$.

Maisonpierre, 1990b), as well as in the brain (Whittemore et al., 1988; Gall and Isackson, 1989; Ernfors et al., 1990a,b; Maisonpierre et al., 1990a; Isackson et al., 1991). Studies of expression of any of the three neurotrophins in development have been either confined to tissue from early postnatal animals (Korsching and Thoenen, 1983; Rohrer et al., 1988; Clegg et al., 1989; Hohn et al., 1990; Maisonpierre et al., 1990b) or devoted to other regions such as the CNS (Maisonpierre et al., 1990a,b; Friedman et al., 1991a,b) and the facial skin (Davies et al., 1987). The great vessels have not been specifically examined in adult or developing animals.

The distribution of mRNAs for all three neurotrophins in the walls of the elastic arteries is bilaminar and located in the tunica media and to some extent in the subendothelial layer. Apart 
Figure 12. $A$ and $B$ show hybridization of the low-molecular-weight NGF-R cRNA probe in sagittal sections through an E15 embryo, showing hybridization over cells of the ventral horn of the spinal cord $(V H)$, the dorsal root ganglia $(D G)$, and stellate ganglion $(S G)$ and in other parts of the sympathetic chain (arrows in $A$ ), a pattern distinct from that seen with the neurotrophin cRNA probes (compare with Fig. 11). Scale bar, $100 \mu \mathrm{m}$.
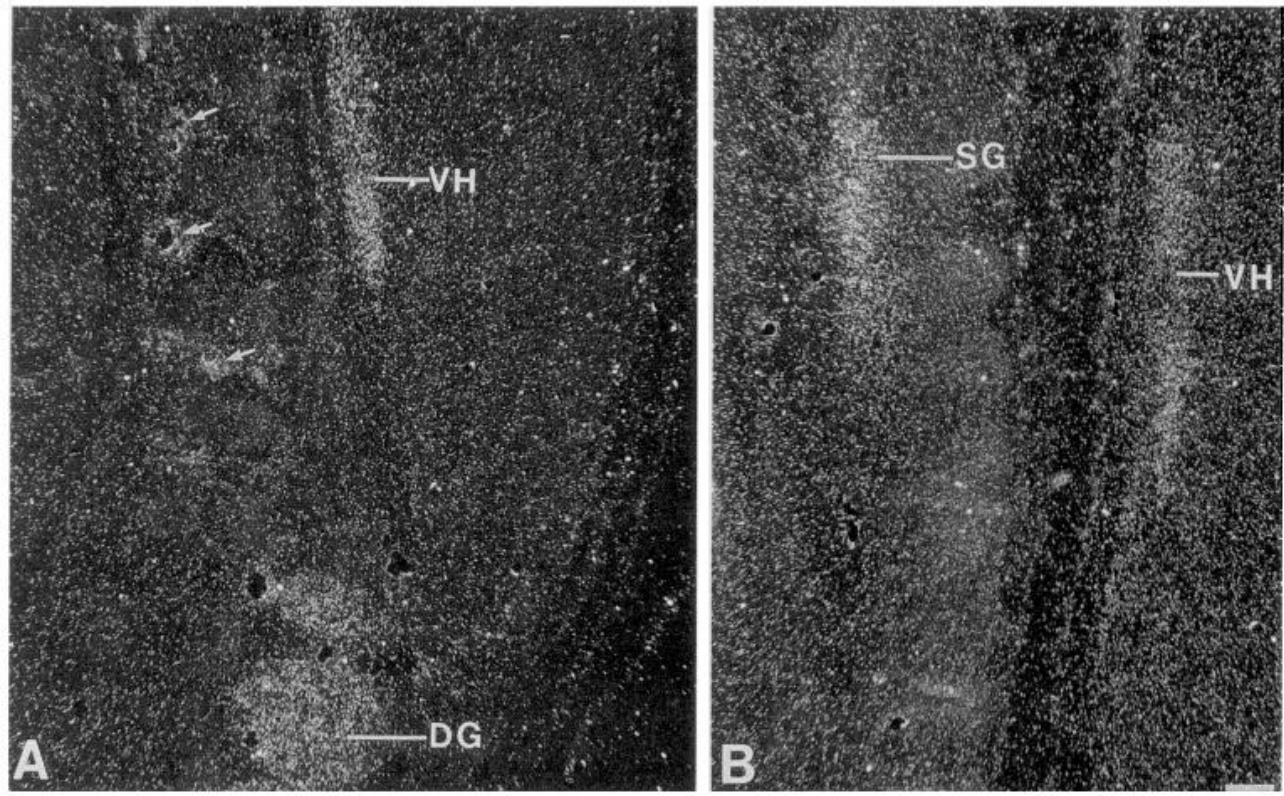

from elastic and collagen fibers, the tunica media is composed of large numbers of smooth muscle cells (Nakamura, 1988), which in the chick originate from the ectodermal germ layer as neural crest-derived ectomesenchymal cells (Le Lievre and Le Douarin, 1975). These are the targets of both sympathetic and sensory fibers (Kuntz, 1934), whose parent cells may, therefore, depend on the production of one or more of the neurotrophins. The absence of any other significant cell type in the tunica media and the morphology of the labeled cells suggest that smooth muscle cells are the sources of mRNAs for all three neurotrophins. The cell types producing the three neurotrophins in the subendothelial layer are less easily identified. This layer is composed of fibroblasts and smooth muscle cells, both of which are potential sources. The neurosensory cells of the carotid sinus and the carotid and aortic bodies, which are diffusely scattered in the aortic arch in the vicinity of the obliterated ductus arteriosus in adults (Heymans and Neil, 1958; Milnor, 1974), are also likely sources of neurotrophins on account of their rich sensory innervation, by both vagal and dorsal root ganglion cell axons (Bouman et al., 1968), but these cells could not be separately identified in the present preparations.

The present methods do not permit us to determine whether mRNAs for the three neurotrophins are expressed in the same or different cells. The homogeneity of labeling with riboprobes for all three, however, and their overlapping distribution in the vessels suggest that the former is a likely possibility. Previous studies in the CNS and in peripheral tissues in adult or postnatal animals have shown that all three factors or their mRNAs appear together in some regions, for example, the hippocampus or heart, but show reciprocal distributions in other regions (Ernfors et al., 1990b; Maisonpierre et al., 1990b; Isackson et al., 1991). The overlapping expression of all three neurotrophins and the likelihood that all three may be expressed within the same cell suggest that a single postganglionic or sensory neuron may be responsive to more than a single member of this neurotrophin family (Davies et al., 1986). Multiple receptors for NGF have been identified (Massague et al., 1981; Hosang and Shooter, 1985). Members of the tyrosine protein kinase family, $\operatorname{trk\mathrm {A}}, \operatorname{trk\mathrm {B}}$, and $t r k \mathrm{C}$, have been identified as specific receptors for NGF, BDNF, and NT-3, respectively (Klein et al., 1991; Lamballe et al., 1991; Soppet et al., 1991; Squinto et al., 1991). There is some cross-reactivity between the trk receptors in that NT-3, in addition to BDNF, binds the trkB tyrosine protein kinase, and NT-3 binds trkA tyrosine protein kinase with a lower affinity than NGF (Cordon-Cardo et al., 1991; Squinto et al., 1991). The low-molecular-weight NGF-R, examined in this study, binds all three neurotrophins with equal affinity (Rodriguez-Tebar et al., 1990; Squinto et al., 1991). It is not clear if the $t r k$ family members can form biologically active high-affinity receptors without the low-molecular-weight receptor (Hempstead et al., 1991; Klein et al., 1991). The coexpression of the three neurotrophic factors within different regions of the developing and adult rat leaves open the possibility of heterodimerization between the neurotrophic factors. It is thus not yet possible to determine which cells in the developing rat are responsive to each neurotrophin since the structure and localization of the functional receptors are not fully known.

The absence or extremely low level of detectable expression of the neurotrophins in the heart was surprising in view of previous reports of the trophic activity of cardiac ventricular tissue (Ebendal, 1979) and of localization by Northern blot analysis of the mRNAs for NGF, BDNF, and NT-3 (Maisonpierre et al., 1990b) particularly in the ventricles. In contrast to the results of Northern blot analyses, very little or no hybridization was found over the cardiac muscle cells of the atria and ventricles, although significant levels appeared in the coronary vessels at $\mathrm{P} 0$ and in the adult. The presence of neurotrophin mRNAs in the coronary vessels and the particularly intense levels in the walls of the aorta and pulmonary artery as they exit from the ventricles, coupled with the difficulty of dissecting the atria and ventricles free of the origins of the great vessels, could therefore have led to an overestimation of ventricular neurotrophin mRNA abundance in the earlier studies. The possibility of contamination of ventricular samples with arterial tissue was addressed in the present study by S1 nuclease protection assays. These illustrate that when ventricular tissue is isolated without pul- 



Figure 13. Control sections from brains of postnatal rats prepared by the same methods used to demonstrate mRNA localization in fetal animals. Adjacent transverse paraffin sections from a $\mathrm{P} 0(A-C)$ and a $\mathrm{P} 7(D-F)$ animal showing little or no hybridization of NGF $(A)$ and only low levels of BDNF $(B)$, but intense hybridization of the NT-3 probe $(C)$. At P7, NGF $(D)$ and $\operatorname{BDNF}(E)$ hybridization has increased and NT - 3 hybridization $(F)$ remains intense in cingulate cortex $(\mathrm{Cg})$, hippocampal formation $(H F)$, and thalamus $(T H)$. Scale bars, $50 \mu \mathrm{m}$. monary artery or aortic contamination, lower levels of neurotrophin mRNA are detected. The remaining signal may be due largely to the presence of neurotrophin mRNA in the coronary arteries. It is possible, however, that the in situ hybridization method used in this study may be insufficiently sensitive to detect very low levels of mRNAs in the ventricles proper, or that the exposure time sufficient to detect the extremely robust label in the arteries was insufficient to reveal significant label in the heart proper. A similar reservation should be expressed regarding the lack of expression seen in the prenatal brain under the conditions of this study.

Although cells expressing hybridizable NGF, BDNF, and NT-3 mRNAs could not be detected in the embryonic CNS under the conditions of this study, intense NT-3 expression was detected in the newborn cingulate cortex, hippocampal formation, and certain thalamic nuclei in $\mathrm{P} 0$ tissue processed under the same conditions. This is in agreement with previous reports (Friedman et al., 1991a) and strongly suggests that the first significant expression of NT-3 in the CNS occurs between E19 and birth. Hybridization obtained on $\mathrm{P} 7$ showed the continued robust expression of NT-3 and an increase in BDNF and NGF expression in the postnatal hippocampal formation as reported by others (Large et al., 1986; Friedman et al., 1991a,b, unpublished observations).

\section{Temporal distribution}

The level of expression of mRNA for each neurotrophin varies over time. This suggests that responsive neurons may exhibit a differential dependence on the three neurotrophins as devel- opment proceeds. The intensity of BDNF probe hybridization was initially lower than the other two in fetuses, but increased progressively and by E18 became intense. The most intense hybridization was consistently obtained with the NT-3 riboprobe up until E18; at postnatal ages and in the adult, levels were similar to those obtained with the BDNF riboprobe. Hybridization with the NGF riboprobe progressively increased until E1 8 but at that age and at P0 was always lower than the other two and was significantly less in the adult. Previous Northern blot studies in rats reported that NT-3 mRNA levels were high in the heart at birth but declined with age, while BDNF mRNA levels were low at birth but increased in both the heart and certain regions of the CNS after birth (Maisonpierre et al., 1990b). NGF mRNA levels were reported to rise in the ventricles from E17 to a peak at P10-P14 (Clegg et al., 1989). NGF protein has been reported in the heart ventricle as early as E12, rising to a peak at E14, declining dramatically at birth, and then rising to a second peak between P4 and P14 before declining to lower levels that are maintained into adulthood (Korsching and Thoenen, 1983). In both investigations, it was considered that levels first became detectable at the time when sympathetic innervation of the heart would be occurring. It is possible that earlier studies were confounded by inclusion of arterial tissue in heart samples.

Temporal changes in growth factor production by target tissue suggest that there may be critical periods of development in which the same population of neurons may be responsive to a different neurotrophic factor(s). The changes in expression found in the present and previous related studies therefore suggest that 
NGF is important during early development of the cardiovascular system but its role is reduced in adult animals, that BDNF becomes increasingly important at latter stages of embryonic development including adulthood, and that NT-3 plays a prominent role at all ages. A developmentally dependent susceptibility of sensory neurons to NGF and BDNF has been previously demonstrated (Gorin and Johnson, 1979; Johnson et al., 1980; Lindsay et al., 1985), and at certain early stages of development the application of both NGF and BDNF to cultured dorsal root ganglion cells shows an additive effect (Lindsay et al., 1985). Also, while sensory neurons are dependent on both NGF and BDNF early in development, the majority later become dependent exclusively on either NGF or BDNF (Acheson et al., 1987).

Vagal and sympathetic fibers reach the primitive cardiopulmonary plexus in the vicinity of the base of the rat heart and the proximal portions of the great vessels on E12 (Gomez, 1958; De Champlain et al., 1970; Owman et al., 1971). These observations correlate with the patterns of HNK-1 and NCAM immunoreactivity seen in the present study. The lack of neurotrophin expression found in the present study before E13 indicates that the newly arriving fibers and cells are not attracted to their targets by NGF, BDNF, or NT-3. By E13, fibers immunoreactive for NCAM and HNK-1 are clearly visible in the developing tunica media and adventitia of the aortic arch derivatives, and it is at this stage that intense neurotrophin expression appears. This correlates also with the first appearance of the precursors of smooth muscle cells in the walls of the great vessels (Nakamura, 1988).

Sympathetic axons that form the major innervation of the heart ventricles and coronary arteries (Mitchell, 1956) are reported only at approximatcly the timc of birth, and maturation of cardiac innervation in the rat may not occur until some time within the second postnatal month (Navaratnam, 1965; Ursell et al., 1990). The early expression of genes for the three neurotrophins in the large arteries of the neck and trunk may, therefore, correlate with the earlier innervation of these structures and the onset of reflex control of the vasculature in the fetus. The later expression in the coronary arteries appears to correlate with the later maturation of their innervation.

\section{Specificity of neurotrophins for the neuronal populations innervating the cardiovascular system}

The coexpression of mRNAs for the three neurotrophins in the same tissue raises the question of whether each represents a factor for a specific subset of innervating neurons. 'I he fibers that appear to form the principal innervation of the aorta and pulmonary artery and their large branches in the thorax are postganglionic sympathetic fibers, parasympathetic fibers, and afferent fibers of vagal and glossopharyngeal nerve origin (Kuntz, 1934; Mitchell, 1956); all have distinct developmental histories. The sympathetic fibers that innervate the smooth muscle cells of the vessels arise from postganglionic neurons of neural crest origin situated in cervical through mid-thoracic sympathetic ganglia (Le Douarin, 1964; Le Lievre and Le Douarin, 1975; Kirby and Stewart, 1983, 1984; Pardini et al., 1989; Kuratani et al., 1991). Afferent fibers of the vagal and glossopharyngeal nerves that innervate the chemoreceptors and baroreceptors arise from cell bodies in the nodose and petrous ganglia that are of placodal origin (Narayanan and Narayanan, 1980; D'AmicoMartel and Noden, 1983). The neural crest in this same region also contributes postganglionic neurons to the cardiac ganglia located in the heart and in the walls of the aorta and pulmonary trunk (Ellison and Hibbs, 1976). Smaller contributions to the sensory innervation of the vessels come from thoracic dorsal root afferents. The parasympathetic fibers to the atrioventricular and sinuatrial nodes arise in the dorsal vagal nucleus of the medulla oblongata.

The innervation of the cardiovascular system is therefore made up of fiber groups arising from neural crest-derived sympathetic, parasympathetic, and sensory neurons, from placode-derived sensory neurons, and from parasympathetic preganglionic neurons of brainstem origin. Neuronal specificity exhibited by the three parent neuronal populations under experimental conditions suggests a likely correlation (1) of NGF and NT-3 with the sympathetic innervation, since these and not BDNF support the survival of embryonic sympathetic neurons in culture (Lindsay et al., 1985; Maisonpierre et al., 1990a); (2) of BDNF and NT-3 with the placode-derived sensory innervation, since they, and not NGF, support the survival of nodose ganglion cells (Johnson et al., 1980; Lindsay et al., 1990; Maisonpierre et al., 1990a; Rosenthal et al., 1990); (3) of NGF, BDNF, and NT-3 with the neural crest-derived sensory neurons, or a subset thereof, since all three support survival of dorsal root ganglion cells in culture (Lindsay et al., 1985; Davies et al., 1986; Kalcheim et al., 1987; Maisonpierre et al., 1990a). Parasympathetic neurons are reported to be unresponsive to NGF or BDNF (Lindsay et al., 1985) or to NT-3 (Rosenthal et al., 1990). Parasympathetic neurons of the ciliary ganglion, however, extend neurites when cocultured with cardiac ventricular tissue (Ebendal, 1979), and both sympathetic and parasympathetic fibers invade ventricular tissue grafted into the anterior chamber of the eye (Tucker and Gist, 1986). The identity of a parasympathetic neurotrophin and any relation it may have to the NGF family remain undetermined. Similarly, any neurotrophin(s) specific for dorsal vagal neurons also remains undiscovered.

An additional possibility is that NGF, BDNF, and/or NT-3 may also act locally in an autocrine or paracrine fashion to promote the survival and differentiation of the neurotrophinproducing smooth muscle cells. This may explain why the receptors for BDNF and NT-3, trkB (Klein et al., 1989, 1990), and $t r k \mathrm{C}$ (L. F. Parada, personal communication) exhibit a widespread distribution in a variety of tissues outside the developing nervous system. These include the aorta and other regions in which we have identified neurotrophin gene expression.

\section{Contribution of mesoectoderm to the rat cardiovascular system}

One of the remarkable features of the pattern of early expression of the threc neurotrophin transcripts was their restriction to the walls of the large elastic arteries: the aorta, pulmonary trunk, ductus arteriosus, and the branches of the first two, namely, the left common carotid, left subclavian, brachiocephalic, and left and right pulmonary arteries. Muscle cells of the tunica media of the major elastic arteries arising from the third, fourth, and sixth aortic arches in the chick differentiate from mesoectodermal neural crest cells (Le Lievre and Le Douarin, 1975), which also contribute to the aorticopulmonary and truncal septum (Kirby et al., 1983; Phillips et al., 1987). In the present study, cells stained by HNK-1 and thus likely to be of neural crest origin (Lipinski et al., 1983; Tucker et al., 1984) were dispersed among non-HNK-1 mesodermal cells within the tunica media of the arteries in the same location as hybridization for the neurotrophins, suggesting a neural crest contribution to these arteries in the rat. Decreasing levels of neurotrophin expression 
within proximal portions of the brachiocephalic, left common carotid, and subclavian arteries correlate with observations in the chick, indicating that these branches of the aorta are chimeras of smooth muscle cells derived from mesoectoderm and from lateral plate mesoderm (Le Lievre and Le Douarin, 1975). Hence, neural crest-derived cells may be the sources of the three neurotrophins in the elastic arteries. Neurotrophin hybridization, however, did not overlap with HNK-1-stained cells located in the heart outside the aorta and pulmonary artery walls.

\section{Localization of $N G F-R M R N A$ in the developing embryo}

The localization of mRNA encoding the low-molecular-weight form of the NGF-R, which binds NGF, NT-3, and BDNF with equal affinity (Rodriguez-Tebar et al., 1990), showed a distribution quite different from that of the neurotrophin mRNAs and was to a large extent in conformity with other recent reports (Huer et al., 1990). Low-molecular-weight NGF-R gene expression could be detected in nerve trunks, sympathetic ganglia, dorsal root ganglia, and the placode-derived trigeminal, nodose, and petrous ganglia. Among these are the sources of all sympathetic and sensory fibers innervating the arteries, that display early, high levels of expression for NT-3, BDNF, and NGF. Expression of the low-molecular-weight NGF-R mRNA in the nodose and petrous ganglia is comparable to that previously observed in the trigeminal ganglion (Davies et al., 1987) and confirmed here. It is a further indication of the likely contribution and importance of NGF and the two homologous neurotrophins, BDNF and NT-3, to the development and maintenance of the efferent and afferent innervation of the great vessels of the neck, thorax, and abdomen.

\section{Appendix}

\begin{tabular}{|c|c|}
\hline \multicolumn{2}{|c|}{ Abbreviations } \\
\hline A & aorta \\
\hline At & atrium \\
\hline B & bronchus \\
\hline $\mathrm{C}$ & coelom \\
\hline $\mathrm{Cg}$ & cingulate cortex \\
\hline DA & ductus arteriosus \\
\hline DG & dorsal root ganglion \\
\hline DR & dorsal root \\
\hline FB & forebrain \\
\hline $\mathbf{H}$ & hypoglossal nerve \\
\hline HB & hindbrain \\
\hline HF & hippocampal formation \\
\hline $\mathbf{I}$ & tunica intima \\
\hline IVC & inferior vena cava \\
\hline $\mathrm{L}$ & lung \\
\hline Lv & liver \\
\hline $\mathbf{M}$ & tunica media \\
\hline Mk & Meckel's cartilage \\
\hline $\mathbf{N}$ & notochord \\
\hline $\mathrm{Pa}$ & pulmonary artery \\
\hline PT & pulmonary trunk \\
\hline $\mathbf{S}$ & sympathetic chain \\
\hline $\mathrm{Sb}$ & subclavian artery \\
\hline SC & spinal cord \\
\hline $\mathrm{SCV}$ & superior vena cava \\
\hline SG & stellate ganglion \\
\hline So & somite \\
\hline $\mathrm{T}$ & trachea \\
\hline Th & thymus \\
\hline $\mathrm{IH}$ & thalamus \\
\hline V & ventricle \\
\hline VH & ventral horn \\
\hline VR & ventral root \\
\hline $\mathbf{X}$ & vagus nerve \\
\hline
\end{tabular}

\section{References}

Acheson A, Barde Y-A, Thoenen H (1987) High K+-mediated survival of spinal sensory neurons depends on developmental stage. Exp Cell Res 170:56-63.

Aguayo AJ, Peyronnard JM, Terry LC, Romine JS, Bray GM (1976) Neonatal neuronal loss in rat superior cervical ganglia: retrograde effects on developing preganglionic axons and Schwann cells. J Neurocytol 5:137-155.

Alderson RF, Alterman AL, Barde Y-A, Lindsay RM (1990) Brainderived neurotrophic factor increases survival and differentiated functions of rat septal cholinergic ncurons in culturc. Neuron 5:297-306.

Bandtlow CE, Heumann R, Schwab ME, Thoenen H (1987) Cellular localization of nerve growth factor synthesis by in situ hybridization. EMBO J 6:891-899.

Barde Y-A, Edgar D, Thoenen H (1982) Purification of a new neurotrophic factor from mammalian brain. EMBO J 1:549-553.

Bouman LN, Mackaay AJC, Bleeker WK, Becker AE (1968) Pacemaker shifts in the sinus node: effects of vagal stimulation, temperature and reduction of extracellular calcium. In: The sinus node (Bonke FIM; ed), pp 245-257. The Hague: Nijhoff.

Bronner-Fraser M (1986) Analysis of the early stages of trunk neural crest migration in avian embryos using monoclonal antibody HNK1. Dev Biol 115:44-55.

Chirgwin JM, Przbyla AE, MacDonald RJ, Rutter WJ (1979) Isolation of biologically active ribonucleic acid from sources enriched in ribonuclease. Biochemistry 118:5294-5299.

Clegg DO, Large TH, Bodary SC, Reichardt LF (1989) Regulation of nerve growth factor mRNA levels in developing rat heart ventricle is not altered by sympathectomy. Dev Biol 134:30-37.

Cohen S (1960) Purification of a nerve-growth promoting protein from the mouse salivary gland and its neurotoxic antiserum. Proc Natl Acad Sci USA 46:302-311.

Cordon-Cardo C, Tapley P, Jing S, Nanduri V, O'Rourke E, Lamballe F, Kovary K, Jones K, Reichardt LF, Barbacid M (1991) The trk tyrosine protein kinase mediates the mitogenic properties of nerve growth factor and neurotrophin-3. Cell 66:173-183.

D'Amico-Martel A, Noden DM (1983) Contributions of neural crest and placodal cells to avian cephalic peripheral neurons. Am J Anat 166:445-468.

Danielson PA, Forss-Petter S, Brow MA, Calavetta L, Douglass J, Milner RJ, Sutcliffe JG (1988) p1B15: a cDNA clone of the rat mRNA encoding cyclophilin. DNA 7:261-267.

Davies AM, Thoenen H, Barde Y-A (1986) The response of chick sensory neurons to brain-derived neurotrophic factor. J Neurosci 6:1897-1904.

Davies AM, Bandtlow C, Heumann R, Korsching S, Rohrer H, Thoenen $\mathrm{H}$ (1987) Timing and site of nerve growth factor synthesis in developing skin in relation to innervation and expression of the receptor. Nature 326:353-358.

De Champlain J, Malmfors T, Olson L, Sachs C (1970) Ontogenesis of peripheral adrenergic neurons in the rat. Pre- and postnatal observations. Acta Physiol Scand 80:276-288.

Ebendal T (1979) Stage-dependent stimulation of neurite outgrowth exerted by nerve growth factor and chick heart in cultured embryonic ganglia. Dev Biol 72:276-290.

Ellison JP, Hibbs RG (1976) An ultrastructural study of mammalian cardiac ganglia. J Mol Cell Cardiol 8:89-101.

Ernfors P, Ibanez CF, Ebendal T, Olson L, Persson H (1990a) Molecular cloning and neurotrophic activities of a protein with structural similarities to beta-nerve growth factor: developmental and topographical expression in the brain. Proc Natl Acad Sci USA 87: 5454-5458.

Ernfors P, Wetmore C, Olson L, Persson H (1990b) Identification of cells in rat brain and peripheral tissues expressing mRNA for members of the nerve growth factor family. Neuron 5:511-526.

Friedman WJ, Ernfors P, Persson H (1991a) Transient and persistent expression of NT-3/HDNF $m$ RNA in the rat brain during postnatal development. J Neurosci 11:1577-1584.

Friedman WJ, Olson L, Persson H (1991b) Cells that express brainderived neurotrophic factor mRNA in the developing postnatal rat brain. Eur J Neurosci 3:688-697.

Gall CM, Isackson PJ (1989) Limbic seizures increase neuronal production of messenger RNA for nerve-growth factor. Science 245: $758-761$. 
Gomez H (1958) The development of the innervation of the heart in the rat embryo. Anat Rec 130:53-71.

Gorin PD, Johnson EM (1979) Experimental autoimmune model of nerve growth factor deprivation: effects on developing peripheral sympathetic and sensory neurons. Proc Natl Acad Sci USA 76:5382-5386.

Hamburger V, Levi-Montalcini R (1949) Proliferation, differentiation and degeneration in the spinal ganglia of the chick embryo under normal and experimental conditions. J Exp Zool 111:457-501.

Hamburger V, Brunso-Bechtold JK, Yip JW (1981) Neuronal death in the spinal ganglia of the chick embryo and its reduction by nerve growth factor. J Neurosci 1:60-71.

Hefti F (1986) Nerve growth factor promotes survival of septal cholinergic neurons after fimbrial transections. J Neurosci 6:2155-2162.

Hempstead BL, Martin-Zanca D, Kaplan DR, Parada LF, Chao MV (1991) High-affinity NGF binding requires coexpression of the trk proto-oncogene and the low-affinity NGF receptor. Nature 350: 678-683.

Hendry IA, Campbell J (1976) Morphometric analysis of rat superior cervical ganglion to axotomy and nerve growth factor. J Neurocytol 6:299-309.

Heymans C, Neil E (1958) Reflexogenic areas of the cardiovascular system. Boston: Little Brown.

Hohn A, Leibrock J, Bailey K, Barde Y-A (1990) Identification and characterization of a novel member of the nerve growth/brain-derived neurotrophic factor family. Nature 344:339-341.

Hosang M, Shooter EM (1885) Molecular characteristics of nerve growth factor receptors on PC12 cells. J Biol Chem 260:655-662.

Huer JG, Fatemie-Nainie S, Wheeler EF, Bothwell M (1990) Structure and developmental expression of the chicken NGF receptor. Dev Biol 137:287-304.

Isackson PJ, Huntsman MM, Murray KD, Gall CM (1991) BDNF mRNA expression is increased in adult rat forebrain after limbic seizures: temporal patterns of induction distinct from NGF. Neuron 6:937-948.

Johnson EM, Gorin PD, Brandeis LD, Pearson J (1980) Dorsal root ganglion neurons are destroyed by exposure in utero to maternal antibody to nerve growth factor. Science 210:916-918.

Johnson JE, Barde Y-A, Scliwab M, Thoenen H (1986) Brain derived neurotrophic factor supports the survival of cultured rat retinal ganglion cells. J Neurosci 6:3031-3038.

Kalcheim C, Barde Y-A, Thoenen H, Le Douarin NM (1987) In vivo effect of brain-derived neurotrophic factor on the survival of developing dorsal root ganglion cells. EMBO J 6:2871-2873.

Kirby ML, Stewart DE (1983) Neural crest origin of cardiac ganglion cells in the chick embryo: identification and extirpation. Dev Biol 97: 433-443.

Kirby ML, Stewart DE (1984) Adrenergic innervation of the developing chick heart: neural crest ablations to produce sympathetically aneural hearts. Am J Anat 171:295-305.

Kirby ML, Gale TF, Stewart DE (1983) Neural crest cells contribute to normal aorticopulmonary septation. Science 220:1059-1061.

Klein R, Parada LF, Coulier F, Barbacid M (1989) trkB, a novel tyrosine protein kinase receptor expressed during mouse neural development. EMBO J 8:3701-3709.

Klein R, Martin-Zanca D, Barbacid M, Parada LF (1990) Expression of the tyrosine kinase receptor gene $\operatorname{trk} B$ is confined to the murine embryonic and adult nervous system. Development 109:845-850.

Klein R, Conway D, Parada, LF, Barbacid M (1991) The trk protooncogene encodes a receptor for nerve growth factor. Cell 61:647-656.

Korsching A, Thoenen H (1983) Nerve growth factor in sympathetic ganglia and corresponding target organs of the rat: correlation with density of sympathetic innervation. Proc Natl Acad Sci USA 60: 3513-3516.

Kuntz A (1934) The autonomic nervous system. Philadelphia: Lea and Febiger.

Kuratani SC, Miyagawa-Tomita S, Kirby ML (1991) Development of cranial nerve in the chick embryo with special reference to the alterations of cardiac branches after ablation of the neural crest. Anat Embryol (Berl) 183:501-514.

Lamballe F, Klein R, Barbacid M (1991) trkC, a new member of the trk family of tyrosine protein kinases, is a receptor for neurotrophin3. Cell 66:967-979.

Large TH, Bodary SC, Clegg DO, Weskamp G, Otten U, Reichardt LF (1986) Nerve growth factor gene expression in the developing rat brain. Science 234:352-355.
Le Douarin N (1982) The neural crest (Barlow PW, Green PB, Wylie CC, eds). Cambridge: Cambridge UP.

Le Douarin NM (1964) Etude experimentale de l'organogenése du tube digestif et du foi chez l'embryon de poulet. Bull Biol Fr Belg 98: 544-676.

Leibrock J, Lottspeich F, Hohn A, Hofer M, Hengerer B, Masiakowski $P$, Thoenen H, Barde $Y-\Lambda$ (1989) Molecular cloning and expression of brain-derived neurotrophic factor. Nature 341:149-152.

Le Lievre C, Le Douarin NM (1975) Mesenchymal derivatives of the neural crest: analysis of chimeric quail and chick embryos. J Embryol Exp Morphol 34:125-154.

Levi-Montalcini R, Angeletti PU (1968) Nerve growth factor. Physiol Rev 48:538-569.

Levi-Montalcini R, Booker B (1960a) Excessive growth of the sympathetic ganglia evoked by a protein isolated from mouse salivary glands. Proc Natl Acad Sci USA 46:373-383.

Levi-Montalcini R, Booker B (1960b) Destruction of sympathetic ganglia in mammals by an antiserum to nerve growth protein. Proc Natl Acad Sci USA 46:384-391.

Lindsay RM, Thoenen H, Barde Y-A (1985) Placode and neural crestderived sensory neurons are responsive at early developmental stages to brain-derived neurotrophic factor. Dev Biol 112:319-328.

Lindsay RM, Maisonpierre P, Squinto S, Yancopoulos GD (1990) Neurotrophin-3 (NT-3): neural specificity in the peripheral nervous system of the chick. Soc Neurosci Abstr 16:991.

Lipinski M, Braham K, Caillaud J-M, Carlu C, Tursz T (1983) HNK-1 antibody detects an antigen expressed on neuroectodermal cells. J Exp Med 158:1775-1780.

Maisonpierre PC, Belluscio L, Friedman B, Alderson RF, Wiegand SJ, Furth ME, Lindsay RM, Yancopoulos GD (1990a) NT-3, BDNF, and NGF in the developing rat nervous system: parallel as well as reciprocal patterns of expression. Neuron 5:501-509.

Maisonpierre PC, Belluscio L, Squinto S, Ip NY, Furth ME, Lindsay RM, Yancopoulos GD (1990b) Neurotrophin-3: a neurotrophic factor related to NGF and BDNF. Science 247:1446-1451.

Massague J, Guillette BJ, Czech MP, Morgan CJ, Bradshaw RA (1981) Identification of a nerve growth factor receptor protein in sympathetic ganglia membranes by affinity labeling. J Biol Chem 256:9419-9424.

McDonald NQ, Lapatto R, Murray-Rust J, Gunning J, Wlodawer A, Blundell TL (1991) New protein fold revealed by a 2.3A resolution crystal structure of nerve growth factor. Nature 354:411-414.

Milnor WR (1974) The cardiovascular control system. In: Medical physiology, 13th ed (Mountcastle VB, ed), pp 958-983. St. Louis: Mosby.

Mitchell GAG (1956) Cardiovascular innervation. London: Livingstone

Nakamura H (1988) Electron microscopic study of the prenatal development of the thoracic aorta in the rat. Am J Anat 181:406-418.

Narayanan CH, Narayanan Y (1980) Neural crest and placode contributions in the development of the glossopharyngeal-vagal complex in the chick. Anat Rec 196:71-82

Navaratnam $V$ (1965) The ontogenesis of cholinesterase activity within the heart and cardiac ganglia in man, rat, rabbit and guinea-pig. J Anat 99:459-467.

$\mathrm{Nja} \mathrm{A}$, Purves D (1978) The effects of nerve growth factor and its antiserum on synapses in the superior cervical ganglion of the guinea pig. J Physiol (Lond) 277:53-75.

Oppenheim RW (1981) Cell death of motoneurons in the chick embryo spinal cord. V. evidence on the role of cell death and neuromuscular function in the formation of specific peripheral connections J Neurosci 1:141-151.

Oppenheim RW, Maderdrut JL, Wells DJ (1982) Cell death of motoneurons in the chick embryo spinal cord. VI. Reduction of naturally occurring cell death in the thoracolumbar column of Terni by nerve growth factor. J Comp Neurol 210:174-189.

Owman C, Sjoberg NO, Swedin G (1971) Histochemical and chemical studies of pre- and postnatal development of the different systems of "short" and "long" adrenergic neurons in peripheral organs of the rat. Z Zellforsch Mikrosk Anat 116:319-341.

Pardini BJ, Lund DD, Schmid PG (1989) Organization of the sympathetic postganglionic innervation of the rat heart. J Autonom Nerv Syst 28:193-202.

Phillips MT, Kirby ML, Forbes G (1987) Analysis of cranial neural crest distribution in the developing heart using quail-chick chimeras. Circ Res 60:27-30. 
Raphael Y, Volk T, Crossin KL, Edelman GM, Geiger B (1988) The modulation of cell adhesion molecule expression and intercellular junction formation in the developing avian inner ear. Dev Biol 128: 222-235.

Reddy EP (1983) Nucleotide sequence analysis of the T24 human bladder carcinoma oncogene. Science 220:1061-1063.

Rodriguez-Tebar A, Dechant G, Barde Y-A (1990) Binding of brainderived neurotrophic factor to the nerve growth factor receptor. Neuron $4: 487-492$.

Rohrer H, Heumann R, Thoenen H (1988) The synthesis of nerve growth factor (NGF) in developing skin is independent of innervation. Dev Biol 128:240-244.

Rosenthal A, Goeddel DV, Nguyen T, Lewis M, Shih A, Laramee GR, Nikolics K, Winslow JW (1990) Primary structure and biologica activity of a novel human neurotrophic factor. Neuron 4:767-773.

Shaner RF (1930) On the development of nerves to the mammalian heart. Anat Rec 46:23-39.

Shelton DL, Reichardt LF (1984) Expression of the beta-nerve growth factor gene correlates with the density of sympathetic innervation in effector organs. Proc Natl Acad Sci USA 81:7951-7955.

Soppet D, Escandon E, Maragos J, Middlemas DS, Reid SW, Blair J, Burton LE, Stanton BR, Kaplan DR, Hunter T, Nikolics K, Parada LF (1991) The neurotrophic factors brain-derived neurotrophic fac- tor and neurotrophin-3 are ligands for the $t r k B$ tyrosine kinase receptor. Cell 65:885-893.

Squinto S, Stitt TN, Aldrich TH, Davis S, Bianco SM, Radziejewski C, Glass DJ, Masiakowski P, Furth ME, Valenzuela DM, DiStefano PS, Yancopoulos GD (1991) trkB encodes a functional receptor for brain-derived neurotrophic factor and neurotrophin-3 but not nerve growth factor. Cell 65:895-903.

Tucker DC, Gist R (1986) Sympathetic innervation alters growth and intrinsic heart rate of fetal rat atria maturing in oculo. Circ Res 59: 534-544.

Tucker GC, Aoyama M, Lipinski M, Tursz T, Thiery JP (1984) Identical reactivity of monoclonal antibodies HNK-1 and NC-1: conservation in vertebrates on cells derived from the neural primordium and on some leucocytes. Cell Differ 14:223-230.

Ursell PC, Ren CL, Danilo P Jr (1990) Anatomic distribution of autonomic neural tissue in the developing dog heart. I. Sympathetic innervation. Anat Rec 226:71-80.

Vincent M, Thiery J-P (1984) A cell surface marker for neural crest and placode cells: further evolution in peripheral and central nervous system. Dev Biol 103:468-481.

Whittemore SK, Friedman PL, Larhammar D, Persson H, Gonzalez CM, Holets VR (1988) Rat beta-nerve growth factor sequence and site of synthesis in the adult hippocampus. J Neurosci Res 20:403-417. 